\title{
Seafloor authigenic carbonate crusts along the submerged part of the North Anatolian Fault in the Sea of Marmara: Mineralogy, geochemistry, textures and genesis
}

\author{
Çağatay Namik M. ${ }^{1,{ }^{*}}$, Yildiz Güliz ${ }^{1}$, Bayon Germain ${ }^{2}$, Ruffine Livio ${ }^{2}$, Henry Pierre ${ }^{3}$
}

\author{
${ }^{1}$ İstanbul Technical University, EMCOLand Department of Geological Engineering Maslak, Faculty of \\ Mining, Istanbul, Turkey \\ ${ }^{2}$ IFREMER, Marine Geosciences Research Unit, 29280 Plouzané, France \\ ${ }^{3}$ Aix Marseille Univ., CNRS, IRD. Coll. France, CEREGE, Aix-en-Provence, France \\ *Corresponding author : M. Namik Çağatay, email address : cagatay@itu.edu.tr
}

\begin{abstract}
:
Extensive seafloor authigenic carbonate crusts occur as pavements, mounds and chimneys along the North Anatolian Fault System (NAFS) in the Sea of Marmara. They are often covered or surrounded by patches of black Fe-sulphide-rich sediments, and associated with hydrocarbon-rich gas and brackishwater emissions in the $1250 \mathrm{~m}$-deep deep basins and with deep saline formation waters and hydrocarbons emissions from mud volcanoes and anticlines on the 350 to $650 \mathrm{~m}$-deep compressional highs.
\end{abstract}

The authigenic carbonate crusts are commonly porous with sinter-like, botryoidal and sugary- granular textures, and constructed from cementation of framework elements consisting mainly of bivalve shells and shell fragments, serpulid tubes, fibrous microbial organic matter and rarely pebbles. The authigenic cements consist mainly of aragonite in most sites, but high Mg-calcite occurs as a major carbonate cement at some basinal sites, where the brackish former Marmara "Lake" waters emerge. The buoyant emission of brackish waters in the deep Marmara basins and deeply sourced fluids from the Tertiary Thrace basin at the compressional highs are supported by relatively low $\delta 180$ values $(+0.5 \%$ to $+3.8 \%$ o $\mathrm{V}$-PDB, average $=+2.1 \% \mathrm{~V}$-PDB, $\mathrm{n}=24)$ of carbonates in the former and high values $(+2.6 \%$ to $+3.4 \% \mathrm{~V}$ $\mathrm{PDB}$, average $=+3.0 \%, \mathrm{n}=9$ ) in the latter areas.

Low $\delta 13 \mathrm{C}$ values (-47.6\% to $-13.7 \%$ V-PDB, average: $-34.9 \%$ V-PDB, $n=33$ ) and close association with black reduced sediments indicate that the seafloor authigenic carbonates are formed by the anaerobic oxidation of methane (AOM) at or near the seafloor, as result of high methane flux, possibly during periods of high seismic activity. Authigenic carbonates from the Western and Central highs are relatively less depleted in $13 \mathrm{C}$ than those of the deep basin sites, suggesting both microbial and thermogenic methane source for the deep basins carbonates and mainly thermogenic hydrocarbon, with some contribution from the biodegradation of heavy hydrocarbons and gas hydrate dissociation, for carbonates from the compressional highs. U-Th ages of the authigenic carbonates range from less than $1 \mathrm{ka}$ BP to $9.6 \mathrm{ka}$ BP. The age distribution, together with the geochemical and mineralogical data, suggests that different processes such as seismo-tectonics and gas hydrates destabilization might have 
played important role in the authigenic carbonate formation in the Sea of Marmara over the last $10 \mathrm{ka}$.

Keywords : authigenic carbonates, mineral and isotopic compositions, textures and structures, U-Th ages, North Anatolian Fault, Sea of Marmara 


\section{Introduction}

Hydrocarbon-rich cold seeps and associated authigenic carbonates are encountered in various oceanic and marine settings, including active and passive margins, but also in silled marine basins such as the Mediterranean Sea, the Black Sea and the Sea of Marmara (Paull et al., 1985; Kennicutt et al., 1985; Moore et al., 1990; Aloisi et al., 2000, 2002; Peckmann et al., 2001; Charlou et al., 2003; Naehr et al., 2007; Tyler et al., 2003; Campbell, 2006; Birgel et al., 2011; Crémière et al. 2012, 2013). Typically, the fluids are enriched in methane and other hydrocarbons produced by microbial degradation of organic matter or by thermogenic processes. The discharge of methane-rich fluids at the seafloor is usually associated with development of chemosynthetic communities and precipitation of authigenic carbonate deposits. The formation of cold seep carbonates results from the anaerobic oxidation of methane (AOM) (Boetius et al., 2000; Valentine and Reeburg, 2000; Orphan et al., 2001; Niemann et al., 2006; Reeburgh, 2007):

$$
\mathrm{CH}_{4}+\mathrm{SO}_{4}^{2-} \rightarrow \mathrm{HCO}_{3}^{-}+\mathrm{HS}^{-}+\mathrm{H}_{2} \mathrm{O}
$$

The AOM reaction with a high upward methane flux provides the necessary $\mathrm{HCO}_{3}{ }^{-}$and $\mathrm{HS}^{-}$ ions for the precipitation of the authigenic carbonate crusts and Fe-sulphide precipitates at or close to the seafloor (e.g., Aloisi et al., 2000; Peckmann et al., 2001; Greinert et al., 2002; Naehr et al., 2007; Tryon et al., 2010; Peketi et al., 2012; Pierre et al., 2012). Furthermore, the reaction provides food and energy for the chemosynthetic communities observed in the cold seep sites, including the Sea of Marmara (Paull et al., 1984; Bergquist et al., 2003, 2007; Levin and Mendoza, 2007; Ritt et al., 2010, 2012; Quaiser et al., 2011).

In the Sea of Marmara, widespread cold seep activity occurs along the North Anatolian Fault System (NAFS), a major continental transform plate boundary between Eurasian and Anatolian-Aegean plates (Armijo et al., 2005; Geli et al., 2008; Zitter et al., 2008; Dupre et al., 2015). The seafloor is cut by the northern and middle splays of the NAFS. It is composed 


\section{ACCEPTED MANUSCRIPT}

of three deep basins (Tekirdağ, Central and Çınarcık) reaching down to $1270 \mathrm{~m}$ water depth, NE-SW trending transpressional ridges (Central and Western Highs) separating the subbasins, and shelf areas with less than 100 m-depth (Fig. 1). The NAFS generates devastating earthquakes along its $1200 \mathrm{~km}$ length with about $250 \mathrm{yr}$ recurrence time (Parsons et al., 2000; Ambraseys, 2002; Barka et al., 2002). The last major earthquakes occurred in 1912 and 1999 in the west and east of the Sea of Marmara, with Mw=7.4 Mürefte, Ganos earthquake (Aksoy et al., 2010) and the Mw=7.4 İzmit Earthquake (Barka et al., 2002), hence leaving a major part of the Sea of Marmara as a seismic gap that is expected to be filled in by one or more earthquakes in the near future.

Methane-rich fluid emissions from the NAFS in the Sea of Marmara were first discovered on the Western High during the R/V Meteor cruise M44/1 in 1999, only a few months before the $1999 \mathrm{Mw}=7.4$ İzmit Earthquake (Halbach and scientific party, 2000). Following the 1999 İzmit earthquake, strong evidence of gas emissions was detected in the İzmit Gulf water column (Alpar, 1999; Kuşcu et al., 2005). A subsequent cruise (Marmarascarps), operating the ROV Victor 6000, allowed the first observations of widespread fluid emissions, carbonate crusts and chimneys, and reduced sediments in the Western High, Tekirdağ Basin and Central Basin (Armijo et al., 2005). Later on, detailed seafloor observations and sampling of gas, pore waters, sediments, gas hydrates and carbonate crusts were made during Marnaut and Marsite cruises using Nautile manned submersible and ROV Victor 6000 dives in 2007 and 2014 (Henry et al., 2007; Ruffine et al., 2015).

The fluids emanating from NAFS in the Sea of Marmara have a variety of compositions that indicate different contributions from crustal versus mantle-derived fluids having various origins (Bourry et al., 2009; Chevalier et al., 2011; Burnard et al., 2012; Tryon et al., 2010, 2012). Cold seeps and associated carbonate crusts, mounds and chimneys occur along the active faults of the NAFS (Chevalier et al., 2011; Crémière et al. 2012, 2013). The seeps emerge from the basin bounding extensional or transtentional faults as well as from the strike slip segments of the NAFS (Dupré et al., 2015). They commonly occur as diffuse flow with gas bubbles but in some cases the flow is focused with emission of brackish waters, where they form carbonate chimneys. The cold seep sites are associated with black reduced sediments on the seafloor, which are colonized by white to yellow-orange bacterial mats and diverse communities of chemosynthetic benthic fauna, including bivalves, sea urchins and siboglinid polychaete (tube worms), all associated with symbiotic bacteria (Ritt et al., 2010, 2012; Quaiser et al., 2011). 


\section{ACCEPTED MANUSCRIPT}

Previous studies on Marmara Sea authigenic carbonates collected during the Marnaut cruise (2007) include stable isotopes and mineralogical analyses and U-Th dating of seafloor deposits and sedimentary concretions by Crémière et al. $(2012,2013)$. The methane-related seafloor carbonate crusts appear to be associated with seismic activity along the NAFS, and could provide a record of past earthquake activity along the different segments. In the present study we analysed seafloor carbonate crust, mound and chimney samples collected in 2014 during the Marsite cruise (Ruffine et al., this issue), together with some additional samples from the Marnaut cruise (Fig. 1; Henry et al., 2007). The main objectives of this study are: 1) reveal the fluid sources along different fault segments, 2) better constrain the timing of seepages and the mode of formation carbonates, and 3) investigate possible relations between seismic activity and fluid emission. Taken together with the published data from Crémière et al. $(2012,2013)$, the obtained results are discussed in terms of environmental conditions, tectonic setting, origin of fluids and mechanisms of formation of the seafloor authigenic carbonates and black sulphidic sediments along the active faults in the Sea of Marmara.

\section{Background}

\subsection{Geological setting}

The Sea of Marmara is a $280-\mathrm{km}$ long and $80-\mathrm{km}$ wide intracontinental sea located between the Mediterranean and the Black Seas (Fig. 1A). It is connected to the saline Aegean Sea and the Black Sea via the Çanakkale (Dardanelles) and İstanbul (Bosphorus) straits, respectively.

The Sea of Marmara is located on the dextral NAF zone that is a $1200 \mathrm{~km}$ long intracontinental plate boundary connecting East Anatolian convergent zone with the Hellenic subduction zone (Şengör et al., 2014; Le Pichon et al., 2015) (Fig. 1A). The NAF splays into branches east of the Marmara region, forming a westward widening deformation zone under the influence of the N-S extensional Aegean regime (McKenzie, 1972, Taymaz et al., 1991; Şengör et al., 2014; Le Pichon et al., 2015). The most active northern branch of the NAF is the Main Marmara Fault (MMF; Le Pichon et al., 2001) that enters the Gulf of İzmit in the east and is connected to the Ganos-Saros Fault in the west (Fig. 1A). The strike-slip MMF consists of different segments and forms extensional and transpressional bends (Fig. 1A). There are also extensional boundary faults that splay from the Main Marmara Fault and delimit the deep basins. 


\section{ACCEPTED MANUSCRIPT}

The Sea of Marmara evolved on a complex basement that consists of various paleotectonic units of Paleozoic to Paleocene age, their cover rocks and the Eocene to middle Miocene rocks of the Thrace Basin (Turgut et al., 1991; Görür and Okay, 1996; Şengör et al., 2005, 2014). The gas- and minor oil-bearing Thrace Basin extends southward in the western and central parts of the Sea of Marmara where it is cut by the MMF (Görür and Elbek, 2013; Şengör et al., 2014).

The NE-trending, Central and Western Highs separate the Çınarcık, Central and Tekirdağ Basins and rise about $600 \mathrm{~m}$ above their surroundings (Fig. 1A, B, D). The highs are transpressional structures formed penecontemporaneously with the MMF and the deep basins (Fig 1B, D; Fig. 2). The Western High has a rough surface morphology with NE-trending folds, small basins and soft-sediment-deformation and mud-diapiric structures (Figs. 1A, 1B, 2) (Dupré et al., 2015). The high consists of at least $6 \mathrm{~km}$ thick sedimentary sequence (Bayrakc1 et al., 2013), the lower part of which is probably constituted by the EoceneMiocene sedimentary rocks of the Thrace Basin (Görür and Elbek, 2014; Şengör et al., 2014; Le Pichon et al., 2015). The MMF on the Western High consists of two segments with the development of $5 \mathrm{~km}$ long and $1 \mathrm{~km}$ wide, small E-W trending pull-apart basin at the offset in the western part (Fig. 1B). The mud volcanoes north of the MMF are about $250 \mathrm{~m}$ diameter, and characterized by widespread fluid emissions with oil, hydrocarbon gas and brines (Bourry et al., 2009; Tryon et al., 2012; Ruffine et al., this issue b). They are also the sites of gas hydrates occurrence, black reduced sediments, barite precipitates and bacterial mats (Fig 4B).

The Central High is a broad antiform cut by the MMF. Irregular topography is caused mainly by slope creep and erosion (Fig. 1D). Micro-bathymetric mapping and seafloor dive observations indicate that the fault scarps of the MMF on the Central High segment is covered by sediments and that its seafloor expression is less pronounced than that of the other segments, all suggesting a lack of recent fault activity (Armijo et al., 2005; Henry et al., 2007).

\subsection{Oceanographic setting and late Pleistocene-Holocene paleoceanography}

The Sea of Marmara is connected to the saline Aegean Sea (-38.5 psu) and the brackish Black Sea ( $18 \mathrm{psu}$ ) via the Çanakkale (Dardanelles) and İstanbul (Bosphorus) straits with the present-day sill depths of $-65 \mathrm{~m}$ and $-35 \mathrm{~m}$, respectively. The sea is characterized by a twoway water exchange between the adjacent seas with a permanent halocline located at $25 \mathrm{~m}$ water depth (Beşiktepe et al., 1994). The Mediterranean water forming the subhalocline 


\section{ACCEPTED MANUSCRIPT}

waters enters the Sea of Marmara through the Çanakkale Strait as an undercurrent. It flows eastwards slowly over the deep basins and highs, gradually consuming its oxygen content in the bottom waters from $50 \mu \mathrm{mol} / \mathrm{kg}$ in the Tekirdağ Basin, to $25 \mu \mathrm{mol} / \mathrm{kg}$ in the Central Basin and $8 \mu \mathrm{mol} / \mathrm{kg}$ in the Çınarcık Basin (Tryon et al., 2012).

Because of the shallowness of the Çanakkale Strait, the Sea of Marmara lost its connection with the Mediterranean during the glacial periods and became a lacustrine environment during the marine isotope stages (MIS) 2, 3 and 4 (Çağatay et al., 2009, 2015). The last marine reconnection was fully established at $12.55 \mathrm{ka} \mathrm{BP}$ (Çağatay et al., 2015), after the initial connection at $14.7 \mathrm{ka}$ BP (Vidal et al., 2010). Soon after every full connection during MIS-1 and MIS-5, sapropel deposition took place under suboxic-dysoxic conditions (Çağatay et al., 1999, 2000, 2009; Tolun et al., 2002). The salinification of the Sea of Marmara during the marine reconnection was a relatively rapid process (1-2 ka) compared to the freshening by Black Sea outflow after the isolation (10s of ka, Çağatay et al., 2009; Aloisi et al., 2015). Using $\mathrm{Cl}^{-}, \delta^{18} \mathrm{O}$ and $\delta \mathrm{D}$ of Sea of Marmara pore water and a transport model, Aloisi et al., (2015) provided estimates for the salinity ( 4 psu) and $\delta^{18} \mathrm{O}(\sim-10.2 \%$ o SMOW) of the Marmara "Lake" bottom waters before the reconnection.

\subsection{Sampling sites}

\subsubsection{Deep basins}

\section{Tekirdă̆ Basin.}

Marsite dive site DV04 (samples DV04-CC01, DV04-CC04) is located in proximity to the MMF, which is also the southern boundary fault of the Tekirdağ Basin (Fig. 1B, Table 1). In the SE Tekirdağ Basin, the fault turns a few degrees WSW from its E-W orientation on the Western High, and becomes transpressive (Fig. 1B). The seafloor at the sampling sites is covered by $7-15 \mathrm{~cm}$ thick carbonate crusts containing cemented bivalve shells and calcified tube worms. There are also patches of black reduced sediments with inarticulated, dead shells of benthic fauna (bivalves, sea urchin) and few live chemosynthetic biological indicators, which suggests reduced methane gas flux at these sites (Tryon et al., 2012). However, mussels attached to carbonate crusts are observed near chimneys expelling brackish water. The pore water alkalinity of the surface sediments measured in one core in this site is $3.5 \mathrm{mM}$ (unpublished Marnaut data).

DV04-CC01 was sampled $185 \mathrm{~m}$ north of the fault at $1107 \mathrm{~m}$ water depth, where a weak active fluid venting is observed (Fig. 1B). At the sampling site, besides a $15 \mathrm{~cm}$ thick carbonate crust and the underlying black reduced sediment, there are some local patches $(\sim 10$ 


\section{ACCEPTED MANUSCRIPT}

$\mathrm{cm}$ in diameter) of carbonate-cemented bivalve shells (Fig. 3B). Sample DV04-CC04 was collected at $1100 \mathrm{~m}$ water depth, $2 \mathrm{~km}$ northwest of a canyon mouth extending down from the southern Tekirdağ Basin slope (Figs. 1B, 3A). Here the carbonate crust forms an up to $15 \mathrm{~cm}$ thick scarp that is colonized by patches of deep water corals (Fig. 3A).

Three samples analysed by Crémière et al. (2012) at site of the Marnaut (Nautile) dive site 1667 are close to the canyon mouth, where there is a $0.5 \mathrm{~m}$ high, active carbonate chimney or vent referred to as "Jack the Smoker" (Armijo et al., 2005; Burnard et al., 2012). Here, the brackish Marmara "Lake" waters exit through the fault seafloor rupture from a high permeability layer of coarse shelly sand transported via the canyon and buried a few meters below the seafloor (Zitter et al., 2008, 2012).

Sample 1647-R1 is located between two E-W trending subsidiary faults that connect with the boundary fault at the western margin of the Tekirdağ Basin, which itself merges with the Ganos Fault further south (Fig. 1B). At this site active venting of fluids containing mantlederived $\mathrm{He}$ and $\mathrm{CO}_{2}$ can be observed (Burnard et al., 2012; Ruffine, this volume a). Sample 1647-R1 was collected from the carbonate crust on the edge of the active fluid venting site (Fig 3D). Near the venting site, the normal beige, oxic sediment cover contains $1-1.5 \mathrm{~cm}$ diameter boring holes of the pink shrimp, Parapenaeus longirostris (Lucas, 1846) (Artüz, 2006; Öztürk, 2009).

\section{Central Basin.}

Marnaut dive site 1661 (samples 1661-R1 to 1661-R7) is located on the northern boundary fault near the eastern edge of the Central Basin (Fig. 1C, Table 1). Widespread gas emissions occur along the boundary fault and the en-echelon extensional oblique faults (Dupre et al., 2015).

Samples 1661-R1 and 1661-R2 were recovered from -1156 m water depth in the eastern Central Basin (Fig 1C), where the seafloor is covered with a carbonate pavement and local patches of black reduced sediments (Fig. 4A, D). Carbonate pavement is replaced locally by discontinues, $10-25 \mathrm{~cm}$ diameter patches of carbonate crusts with a rough surface.

Sample 1661-R3 is located on a fault scarp at -1159 m water depth, where thinly (1.5$5 \mathrm{~cm}$ ) bedded carbonate slabs were observed with some attached calcified sessile corals. The sample represents a slab measuring $60 \mathrm{~cm}$ x $45 \mathrm{~cm} \times 5 \mathrm{~cm}$ and consisting of an essentially carbonate cemented mudstone. A calcified coral (sample 1661-R3 Coral) attached to the slab was sampled for stable isotope analysis (Table 1). Sample 1661-R4 is recovered from a 3-cm 


\section{ACCEPTED MANUSCRIPT}

thick, dark brown to black, flat, horizontally banded carbonate pavement covering the seafloor at a depth of $-1143 \mathrm{~m}$ (Fig. 4B).

Sample 1661-R5 is recovered from the top of a 2-m high carbonate mound at $-1141 \mathrm{~m}$ water depth (Fig. 4C). The mound appears to have been built by the deposition of irregular carbonate layers on top of each other. Its base is fractured possibly by faulting. No fluid activity was observed in and around the mound at the time of sampling. Seafloor at the site of sample 1661-R6 consists of flat carbonate pavement associated with $5 \mathrm{~mm}$ thick black reduced sediments with scarce dead bivalve shells, and covered by beige to light brown sediments (Fig. 4D). The sample represents a $0.6-0.8 \mathrm{~cm}$ thick carbonate crust with a laminated structure. Sample 1661-R7 was collected from a carbonate pavement, surrounded by patches of black reduced sediments at -1139 m water depth. The sampled crust is dark brown and black on the surface and grey on broken fresh and unexposed surfaces.

\section{Çınarcık Basin.}

An authigenic carbonate sample DV05-CC01 and a calcified coral sample were collected -1237 m depth in southeast Çınarcık Basin (Fig. 1E, Table 1). Crémière et al. (2012) analysed three samples from the same area that is characterized by a set of NW-trending extensional faults, acoustically detectable gas emissions and extensive black reduced sediments (Burnard et al., 2012; Dupré et al., 2015). Sample DV05-CC01 was recovered from a $2 \mathrm{~m}$ diameter and $1 \mathrm{~m}$ high carbonate mound at a water depth of $-1237 \mathrm{~m}$ (Fig. 5A). Black reduced sediment patches and brick-red oxidation colours were observed on and around the carbonate mound. Dead and live deep water corals were attached to the edge of the carbonate mound. The calcified coral sample DV05-Coral2 was collected from a colony near the mound (Fig. 5B).

Sample 1658-R1, analysed by Crémière et al. (2012), was sampled from -1176 m water depth, on a bench formed by mass wasting material from the Palaeozoic rocks forming the steep northern escarpment of the Çınarcık Basin (Figs. 1E). The bench is characterized by gas bubbles seeping through the porous talus material, as observed during the acoustic surveys (Dupré et al., 2015). The area contains numerous Palaeozoic rock blocks of various sizes. The carbonate crusts and carbonate cemented breccia were covered by $10-15 \mathrm{~cm}$ thick soft sediment (Fig. 1E). A $100 \mathrm{~m}$ long and $50 \mathrm{~m}$ wide black patch of reduced sediments with white and orange microbial mats extends along the sampling area (Tryon et al., 2012). Relatively high levels of pore-water alkalinity were observed in the near-surface sediments of 


\section{ACCEPTED MANUSCRIPT}

the Çinarcık Basin, with up to $24 \mathrm{mM}$ in the southeast (dives D05, 1663, 1659) and up to 8 $\mathrm{mM}$ in the north (unpublished Marnaut data) (Fig. 1E).

\subsubsection{Pressure highs}

Western High.

Authigenic carbonate samples 1662-R1, DV02-CC03, 1662-R3, 1662-R4 and 1662-R5 and one barite sample (1666-R1) were located on the two mud volcanoes in the central part of the Western High (Fig. 2). The sampling depths range from -646 to -656 m. (Fig. 1B, Table 1).

The site of sample 1666-R1 (barite) is close to the gas hydrate location and the carbonate mound site on a mud volcano where dense fluid (brine) flow with oil and gas hydrocarbons and barite precipitates are observed (Bourry et al., 2009; Tryon et al., 2012). Barite occurs as 10-15 cm high, $15-25 \mathrm{~cm}$ diameter chimney-like mounds or white flat precipitates surrounded by a halo of black reduced sediments and bacterial mats (Fig. 6B). Sample 1666-R1 is mainly barite with minor carbonate, having a chimney-like morphology and porous texture. Samples DV02-CC03 and 1666-R1 were recovered from -646 m and $656 \mathrm{~m}$ water depth, on the southern mud volcano (Fig. 2). The site of sample DV02-CC03 is characterized by $7-8 \mathrm{~cm}$ high and $20-30 \mathrm{~cm}$ diameter carbonate mounds built mainly by carbonate cementation of bivalves (Fig. 6C).

Five samples (1662-R1 to 1662-R5) were collected on the northern mound (Fig. 2). At the location of the samples, there are flat carbonate crusts and locally developed chimney-like, 5-10 cm diameter and $5 \mathrm{~cm}$ high carbonate mounds, which are surrounded by patches of black reduced sediments with 20-30 cm diameter (Fig. 6A, C, Table 1). The site of sample 1662-R1 consists of discontinuous carbonate crusts with irregular surface and thickness, with some 15$25 \mathrm{~cm}$ in diameter chimney-like crusts or mounds (Fig. 6A). These small chimneys appear to locally merge together forming larger mounds with 2-3 $\mathrm{m}$ in diameter. Samples 1662-R1 to 1662-R3 and sample 1662-R5 were collected from chimney-like crusts, whereas sample 1662-R4 was recovered from flat carbonate crust (Table 1). Gas bubbles were observed during the collection of samples at this site.

\section{Central High.}

Samples 1664-R1 and 1664-R2 are located on an anticline, about $1 \mathrm{~km}$ south of the MMF, where active gas emissions occur (Dupre et al., 2015) (Fig. 1D, Table 1). Sample 1664-R1 is located at $-323 \mathrm{~m}$ water depth, east of the Central High. The authigenic carbonate 


\section{ACCEPTED MANUSCRIPT}

crusts occur as discontinuous patches, containing a rich bivalve colony of mytilids. The sampling area also has patches of black reduced sediments with an outer halo of white bacterial mats. The substrate below the surface sediments is hard and could not be penetrated by push cores, suggesting widespread presence of carbonate crust underlying the sediment cover.

Sample 1664-R2 was recovered at $-326 \mathrm{~m}$ water depth from a carbonate pavement covering an $8 \mathrm{~m} \times 4 \mathrm{~m}$ area, elongated in N-S direction (Fig. 6D). The carbonate pavement is covered by a few $\mathrm{cm}$ thick beige sediment. The surrounding sediments are predominantly beige with patches of black reduced sediments. Some intermittent bubble emissions were observed from small chimney-like structures during the sampling operations.

\section{Sampling and analytical methods}

\subsection{Sampling methods}

A total of 17 seafloor authigenic carbonate samples, one barite sample and two calcified coral samples were collected during the Marnaut (2007) and Marsite (2014) cruises using the Nautile manned submersible and the Victor 6000 ROV, respectively (Henry et al., 2007; Ruffine et al., 2014) (Table 1, Fig. 1B, C, D, E). The sampling was accompanied with seafloor observations, video filming and photography of the sampling sites. The carbonate samples were visually described and photographed in the laboratory. Authigenic carbonate cement material, visibly free of shells, shell fragments and detrital minerals, were microdrilled, powdered and used in the XRD mineralogical, chemical, stable isotopic and UTh dating analyses.

\subsection{Petrographic studies}

Structures and textures of representative sample pieces were studied and characterized at centimetre to micrometre scales, using a binocular microscope, a petrographic microscope, and JEOL JSM-7000F scanning electron microscope (SEM) coupled with an energy dispersive XRF spectrometer (EDS). The samples were coated by platinum and analysed by the SEM using $10 \mathrm{kV}$ voltage.

\subsection{XRD Mineralogical analysis}

Mineralogical analysis of the authigenic carbonate cement, barite and deep water coral samples were carried out a by semi-quantiative X-ray diffraction (XRD). A Bruker D8 Advance X-ray diffractometer equipped with a Lynxeye detector was used for the analysis. 


\section{ACCEPTED MANUSCRIPT}

The powder samples were mounted on concentrically grooved sample holders made of polymethyl methacrylate (PMMA) having $25 \mathrm{~mm}$ diameter. Samples were analyzed using $\mathrm{Cu}$ $\mathrm{K} \alpha$ radiation using opertaing conditions of $30 \mathrm{kV}, 40 \mathrm{~mA}, \Delta^{\circ} 2 \Theta=0.00571346$ step-size and 0.1 second scanning speed. The semi-quantitative estimation of the relative carbonate-mineral percentages (as a percentage of $100 \%$ total carbonate for each sample) were made from the peak heights of main reflections of calcite, high-Mg calcite, aragonite and dolomite at 3.015 $<\mathrm{d}_{104}<3.035,3.975<\mathrm{d}_{104}<3.010,3.396\left(\mathrm{~d}_{111}\right)$, and $2.93\left(\mathrm{~d}_{111}\right)$, respectively (Goldsmith et al., 1961).

\subsection{Stable oxygen and carbon isotope analyses}

The $\delta^{18} \mathrm{O}$ and $\delta^{13} \mathrm{C}$ of authigenic carbonate cement of the samples were measured using an automated carbonate preparation device (KIEL-III) coupled to a gas-ratio mass spectrometer (Finnigan MAT 252) at the Isotope Geochemistry Laboratory of University of Arizona. Powdered bulk samples were reacted with dehydrated phosphoric acid under vacuum at $70{ }^{\circ} \mathrm{C}$. The isotope ratio measurement is calibrated based on repeated measurements of NBS-19 and NBS-18. The precision of the method is $\pm 0.1 \%$ VPDB for $\delta^{18} \mathrm{O}$ and $\pm 0.06 \%$ VPDB for $\delta^{13} \mathrm{C}(1 \sigma)$.

\subsection{Inductively coupled-mass spectrometry-emission spectroscopy (ICP-MS-ES) analysis}

About $0.25 \mathrm{~g}$ of sample powder was dissolved in hot $\mathrm{HNO}_{3}-\mathrm{HClO}_{4}-\mathrm{HF}$ mixture until dryness. The residue was dissolved in $10 \% \mathrm{HCl}$ and the sample solution was analysed for $\mathrm{Ca}, \mathrm{Mg}, \mathrm{Al}$, $\mathrm{Fe}, \mathrm{K}, \mathrm{Mn}, \mathrm{S}, \mathrm{Sr}, \mathrm{Ba}, \mathrm{Rb}, \mathrm{Li}$ and Mo by a combination of ICP-MS and ICP-ES (Bureau Veritas Minerals, 2015). The precision of the method for all the analysed elements is better than $5 \%$ at $95 \%$ confidence level.

\subsection{U-Th analysis and dating}

The chemical procedure used in this study was described in detail by Bayon et al. (2015). Each carbonate cement sample visibly free of shells and shell fragments and detrital minerals was dissolved in 7.5 M HNO3, spiked with a mixed 236U/229Th spike, and digested in concentrated HNO3 on the hotplate. After centrifugation, undissolved residual fractions were fully digested with a mixed (3:1) HF: $\mathrm{HCl}$ solution, and added back into corresponding supernatants for evaporation. $U$ and Th were separated after Fe-oxide co-precipitation using conventional anion exchange techniques. $U$ and $T h$ concentrations and isotope ratios were measured with a MC-ICPMS (Neptune) at the Pôle Spectrométrie Océan (PSO, Brest). 


\section{ACCEPTED MANUSCRIPT}

U-Th carbonate age calculations were performed by the isochron method with the ISOPLOT program (v. 3.71, Ludwig, 2009) in order to correct measured ratios from detrital contamination. For the Marmara Sea samples, the activity ratios used for the detrital endmember are derived from Crémière et al. (2013), determined experimentally by analyzing several representative sediments from the Sea of Marmara.

\section{Results}

\subsection{Petrography}

The studied authigenic carbonates from the Sea of Marmara display a variety of forms including slabs, pavements, mounds and chimneys of variable size and shapes, as described in section 2.3. They are commonly grey on fresh surfaces, but black, dark brown or orange on their oxidized outer surfaces (Figs. 7 and 8). The crusts are often porous, having a spongy and sinter-like structure, and constructed with framework elements of shells and shell fragments of bivalves, serpulid tube worms (polychaete), fibrous microbial organic matter, echinoids, and minor to trace amounts of illite, smectite and quartz.

Samples collected from small carbonate chimneys (e.g., 1662-R1, 1662-R4, Western High) are characterized by irregular surface with common botryoidal structure, with tubular moldic and irregular solution cavities (Figs. 7 and 8). The cavities are partly filled with fibrous aragonite (Fig. 9B). The matrix has a microcrystalline (micritic) cement, and contain abundant mytilid bivalves, gastropods and calcified tube worms (serpulids) and minor echinoids, foraminifera and coccoliths (Figs. 7, 8 and 9). The mytilid bivalves are often articulated with two-valves in their living positions (Fig. 7C), and show close similarities to Idas modiolaeformis Sturany (1896), previously identified by Ritt et al. (2012) in the Sea of Marmara. The serpulid tube worms range in length from a few $\mathrm{mm}$ to several centimetre and in diameter from 0.2 to $1 \mathrm{~mm}$, and constitute an important framework element of carbonate crust structure (Figs. 8B, 8C and 9F). The micritic matrix includes sand-size shell fragments. The carbonate crusts commonly contain less than $0.5 \mathrm{~mm}$ wide, light gray carbonate and brown-orange iron oxyhydroxide veinlets and disseminated oxidized pyrite grains with up to $200 \mu \mathrm{m}$ diameter (Fig. 8D).

Samples recovered from the carbonate mounds (e.g., 1661-R5, DV05-CC01) have ochre, umber and black colours on the surface and grey to dark grey colours on fresh surfaces. They often have botryoidal, banded, and locally sugary and honey-combe structures and textures 


\section{ACCEPTED MANUSCRIPT}

(Fig. 7D, 8A, 9A), and contain only rare $0.5-1 \mathrm{~cm}$ mytilid and $0.5-1 \mathrm{~mm}$ gastropod with no or very little serpulids.

Samples of carbonate pavements (e.g., 1661-R1, 1661-R2, 1661-R6: eastern Central Basin; 1662-R5: Western High; DV04-CC04: Tekirdağ Basin) have various textures and structures with a common porous and spongy appearance (Figs. 7 and 8). Some samples, such as DV04-CC04 in SE Tekirdağ basin, consist of carbonate cemented shells, rounded pebbles and minor mica (Fig. 7C, E and F). The pebbles, most likely transported via the canyon in the south, are covered by filamentous microbial mats (Fig. 7F). The carbonate matrix is grey and contains $0.25-2 \mathrm{~mm}$ diameter and 1.5-5 $\mathrm{mm}$ long serpulids belonging to species Serpula vermicularis (Fig. 8B, C). Sample 1661-R1 from the eastern Central Basin has a porous, sinter-like texture and beige to light grey colours with a local umber colour due to iron oxyhydroxide staining (Fig. 7B). Its framework consists predominantly of serpulid tube worms with a 2-3 $\mathrm{mm}$ diameter and up to $3 \mathrm{~cm}$ laminated and lithified sediment clasts. Macro and microfossils are restricted to only a few juvenile molluscs and echinoid shells and shell fragments of less than $1 \mathrm{~cm}$-size and rare coccoliths and diatoms (Fig. 9F).

Less commonly, the seafloor carbonates forming the pavement or flat slabs (e.g., 1661R3, eastern Central Basin) are highly dense, compact and hard, most likely formed by lithification of seafloor muds by carbonate cementation (Fig. 7A). They are grey on fresh surfaces whereas black, dark brown to beige on their exposed, oxidized surfaces, and contain up to $0.5 \mathrm{~mm}$ in diameter and $10 \mathrm{~mm}$ long serpulid tube worms and very rare bivalve shells (Fig. 8B, C). Locally the carbonate fossils are corroded resulting in moldic porosity (Fig. 7E). The carbonate matrix consists of rice-shaped 3-5 $\mu \mathrm{m}$ long grains of high Mg-calcite (Fig. 9E). The sample includes 10-20 $\mu \mathrm{m}$ long, rare grains of illite-mica, albite and chlorite, confirmed by the EDS analysis.

Detailed SEM observations show that the matrix of the chimney and mound carbonates consists of rosettes of acicular aragonite crystals and rice-like grains of high Mg-calcite (Fig. 9B, E). The matrix also contains microbial organic matter covering the cavity surfaces (Fig. 9C) or occurring as fibrous filamentous mats (Fig. 9D), and rare 10-20 $\mu \mathrm{m}$ clay mineral and less than $1 \mu \mathrm{m}$ pyrite grains. The cavities are lined by at least two different aragonite layers (Fig. 9B). 


\subsection{Mineralogy}

The authigenic carbonates consist mainly of aragonite, with lesser amounts of high $\mathrm{Mg}$ calcite, calcite and local dolomite (Table 2). The XRD analysis also shows that some Central High samples (1664-R1, 1661-R7) and a sample from the SE Tekirdağ Basin (DV04-CC-01) contain minor amounts of pyrite and gypsum. Samples DV05-CC01 and DV04-CC04 contain major amount of quartz, in addition carbonate minerals. Sample DV04-CC04 also includes some illite and minor to trace amounts of smectite, gypsum and pyrite. Pyrite was observed as framboids under the SEM.

\subsection{Elemental composition}

Elemental composition of the authigenic carbonates indicates that the $\mathrm{Ca}$ content ranges from 14.38 to $38.55 \mathrm{wt} \%$, which corresponds to 36.0-96.4 wt $\% \mathrm{CaCO}_{3}$ (Table 3). Samples DV05-CC01 and DV04-CC04 with admixtures of quartz and clay minerals have the lowest $\mathrm{Ca}$ (carbonate) content. $\mathrm{Mg}$ is relatively high (up to $3.06 \mathrm{wt} \%$ ) in the samples containing high Mg-calcite.

Highest S (up to $3.8 \mathrm{wt} \%)$, Fe (3.51 wt\%) and Mo $(55 \mu \mathrm{g} / \mathrm{g})$ occurs in sample DV04CC01 in SE Tekirdağ Basin. Samples with high content of lithofile elements K, Rb and Li are located in the Western High (1662-R1, 1662-R4, 1664-R1), east of Central Basin (1661-R3, 1661-R7) and SE Tekirdağ Basin (DV04-CC04). Ba concentrations higher than $400 \mu \mathrm{g} / \mathrm{g}$ occur mainly in samples located in eastern edge of the Central basin (i.e., samples 1661-R7, 1661-R2, 1661-R4, 1661-R5) and in one sample from SE Tekirdağ Basin (DV04-CC04).

\subsection{Stable isotope composition}

Carbon isotope values of 33 authigenic carbonate samples from the Sea of Marmara range between -47.6 and $-13.7 \%$ V-PDB (Table 2). The relatively heavy carbon isotope values (-13.7 to $-24.9 \%$ V-PDB) are observed on the Western and Central pressure highs. Oxygen isotope values vary within a relatively narrow interval of 1.3 and 3.8\%o V-PDB. The carbon and oxygen isotope values of the corals associated with the carbonate crusts in the Central and Çınarcık Basin are essentially the same with values of $-4.6 \%$ V-PDB and 1.2\%o V-PDB, respectively. The minor amount of carbonate associated with barite sample (1666R1) from the Western High has a relatively high $\delta^{13} \mathrm{C}$ value of $-0.6 \%$ V-PDB and a $\delta^{18} \mathrm{O}$ value of $3.2 \%$ V-PDB. 


\subsection{U-Th ages}

U-Th ages of five seafloor authigenic carbonate cements and one coral sample range between $0.11 \mathrm{ka} \mathrm{BP}$ and 9.61 ka BP (Table 4). One sample (DV04-CC01) is characterized by low $\delta^{234} U$ initial value $(<130)$.

Considering U-Th ages of all 14 seafloor carbonate crusts analysed by this study and Crémière et al. (2013), six samples are recent ( $<1$ ka BP) (Table 2; Fig. 10). The recent samples are all from the Tekirdağ and Çınarcık basins, except for one sample (1664-R2) from the Central High. The other four samples are between $1 \mathrm{ka}$ BP and $4 \mathrm{ka}$ BP, two samples between $6 \mathrm{ka} \mathrm{BP}$ and $7 \mathrm{ka} \mathrm{BP}$ and two samples between $9 \mathrm{ka} \mathrm{BP}$ and $10 \mathrm{ka} \mathrm{BP}$, with gaps between $4 \mathrm{ka} \mathrm{BP}$ and $6 \mathrm{ka} \mathrm{BP}$ and $7 \mathrm{ka} \mathrm{BP}$ and $9 \mathrm{ka} \mathrm{BP}$. The oldest two samples (1661R4 and 1664-R5) with ages of 9.61 ka BP and 9.14 ka BP are from eastern Central Basin. These samples represent a banded seafloor carbonate pavement and the top of the nearby 2 m-high carbonate mound, with their surface covered with a few mm-thick ochre, umber to black Fe-Mn-oxyhydroxides (Fig. 4C).

\section{Discussion}

\subsection{Factors controlling the carbonate mineral composition}

Factors determining the mineralogy of early diagenetic authigenic carbonate mineral in marine and lake basins include the degree of saturation with respect to the carbonate minerals (i.e., $\mathrm{Ca}^{2+}$ and $\mathrm{HCO}_{3}{ }^{-}$activities), $\mathrm{SO}_{4}{ }^{-2}$ concentration, $\mathrm{Mg}^{2+} / \mathrm{Ca}^{2+}$ ratio, temperature, and microbial activity (Mackenzie and Pigott, 1981; Burton and Walter, 1987; Morse at al., 1997; De Choudens-Sanchez and Gonzalez, 2009; Peckmann et al., 2001; Reitner et al., 2005; Naehr et al., 2007). High degree of oversaturation with respect to carbonate minerals and high $\mathrm{SO}_{4}{ }^{-2}$ concentrations favour aragonite over calcite and high $\mathrm{Mg}$-calcite. Such conditions are found at gas seeps, where intense methane fluxes shift the sulfate/methane interface (SMI) near the sediment-seawater interface and result in high alakalinity. Precipitation of dolomite is promoted by high molar $\mathrm{Mg}^{2+} / \mathrm{Ca}^{2+}$ ratio and microbial activity, which commonly occur in the zone of methanogenesis (Mackenzie and Pigott, 1981; Greinert et al., 2001; Çağatay et al., 2001; Orphan et al., 2004; Naehr et al., 2007).

The mineral composition of the authigenic carbonates in the Sea of Marmara appears to vary independently of the tectonic and geographic settings. However, whereas aragonite seems to be the major mineral in the carbonate crusts of the compressional Western and 
ACCEPTED MANUSCRIPT

Central highs, high $\mathrm{Mg}$-calcite with relative percentages greater than $50 \%$ and the samples with $15 \%$ to $50 \%$ calcite, are located predominantly in the basinal sites. Samples $1663-\mathrm{R} 1$ and 1665-R3 in the eastern Central Basin have the highest dolomite with relative percentage of $22 \%$ and $15 \%$, respectively. Minor amounts of dolomite $(<7$ relative carbonate $\%)$ are present in samples from the Central High and in one sample (DV04-CC04) in SE Tekirdağ Basin. Dolomite is considerably more scarce in the seafloor authigenic carbonate samples than in the subsurface authigenic carbonate nodules analysed by Crémière et al. (2013) in cores recovered from the southeast Tekirdağ Basin and Western High. The core from the former site is located near the seepage site of the Marmara "Lake" brackish water (Zitter et al., 2008, 2012), and contains more dolomite than the latter site.

Considering that the sedimentation rate during the marine stage of the Sea of Marmara is 1-2 $\mathrm{m} / \mathrm{kyr}$ in the deep basins and 0.3-0.5 m/kyr over the pressure highs (Çağatay et al., 2000, 2015; Mercier de Lepinay et al., 2003; Beck et al., 2007) and assuming no seafloor erosion, the carbonate crusts exposed on the seafloor should be younger than 1-2 ka, and hence were deposited under similar oceanographic conditions (i.e., under the influence of he subhalocline waters of Mediterranean origin with a constant temperature of $14.5^{\circ} \mathrm{C}$ and $\mathrm{SO}_{4}{ }^{-2}$ concentration of 33 mM; Beşiktepe et al., 1994; Tryon et al., 2010). The seep sites are characaterized by the presence of black sulphidic sediment patches and shallow sulphate/methane interface (SMI) at or near the seafloor, indicating the occurrence of AOM by sulphate reduction and high alkalinity production (e.g., Borowski et al., 1996; Çağatay et al., 2001; Tryon et al., 2010; Crémière et al., 2012). The predominance of aragonite in the seafloor authigenic carbonates in general and the pressure highs in particular, can be explained by the high alkalinity, high $\mathrm{SO}_{4}{ }^{-2}$ concentrations and a relatively high bottom water temperature of $14.5^{\circ} \mathrm{C}$ (e.g., Morse at al., 1997; De Choudens-Sanchez and Gonzalez, 2009; Reitner et al., 2005; Crémière et al., 2012, 2013). Deposition of high Mg-calcite in the SE Tekirdağ Basin and eastern Central Basin authigenic carbonate crusts was likely promoted by relatively low salinity and low $\mathrm{SO}_{4}{ }^{-2}$ concentrations that were caused by the dilution of the bottom waters with the brackish Marmara "Lake" waters known to be emitting at these basinal sites (Zitter et al., 2008; Tryon et al., 2010; Crémière et al., 2012).

In the Çınarcık Basin the carbonate crusts consist mainly of aragonite with minor to trace amounts of high Mg-calcite, except in the mound at dive site DV05, where subequal amounts of aragonite and calcite are present. This site is located on the same extensional fault system where freshening of pore waters with depth, high alkalinity (up to $24 \mathrm{mM} / \mathrm{kg}$ ) and an 


\section{ACCEPTED MANUSCRIPT}

SMI close to the surface were observed a few km westward in the basin (Henry et al., 2007; Tryon et al., 2010). Aragonite, appears to have deposited during a more vigorous outflow of brackish waters with low $\mathrm{SO}_{4}^{-2}$ concentrations (Fig. 8A, 9C and D), whereas calcite more likely deposited later mainly as a pore- and cavity filling cement under seawater-dominated conditions during a waning stage of the brackish water expulsion. However, Crémière et al. (2012) considered calcite to be mainly of biogenic origin. This may be true for samples with less than 15\% calcite but not for samples 1661-R4, DV05-CC01, 1661-R7, DV04-CC04 and 1649-R1 containining between $23 \%$ and $50 \%$ calcite (Table 2). This is because the microdrilled samples excluded visible fossil material. Moreover, the microscopic observations showed that the sampled authigenic carbonate material included less than 5\% microfossils.

On the Western and Central highs, the pore fluids carry the signatures of deep, saline formation waters of the gas and oil bearing Thrace basin, and possibly the gas hydrate formation (Bourry et al., 2009; Tryon et al., 2010) (Fig. 1B, E). In particular, at dive site 1662 on the Western High, outflow of brines from a mud volcano, type II gas hydrates in the sediment at $6 \mathrm{~m}$ below seafloor, seepage of heavy hydrocarbon gases and oil, and barite precipitates are observed (Figs. 2, 3B). The conditions of high hydrocarbon gas flux, high oversaturation with respect to carbonate minerals and high salinity of the fluids on the compressional highs are in agreement with the aragonite being the main carbonate mineral of the authigenic crusts at these sites.

\subsection{Stable isotope composition and origin of the dissolved inorganic carbon}

The $\delta^{13} \mathrm{C}$ values vary widely between $-47.6 \%$ and $-13.7 \%$, and $\delta^{18} \mathrm{O}$ values range between $+1.3 \%$ and $+3.4 \%$ (Table 2 , Fig 11). In general, the high variability in the $\delta^{13} \mathrm{C}$ values can be explained by different sources contributing to the dissolved inorganic carbon (DIC) pool at the time of authigenic carbonate precipitation at a given site (e.g., see Ruffine et al., this issue a). The DIC sources include the anaerobic oxidation of microbial and thermogenic methane (AOM), $\mathrm{CO}_{2}$ produced in the zone of methanogenesis and mantle, biogradation of sedimentary organic matter and heavy hydrocarbons, and detrital and biogenic carbonates (microfossils, shell fragments) cemented within the authigenic carbonate.

Samples with $\delta^{13} \mathrm{C}$ values of $-40 \%$ o to $-20 \%$ are considered to be indicative of a DIC source produced predominantly by anaerobic oxidation of thermogenic methane, whereas values lower than $-40 \%$ are related to isotopic signatures of the anaerobic oxidation of microbial methane (e.g., Naehr et al., 2000, 2007; Orphan et al., 2004). Carbonate nodules consisting of Fe-rich dolomite and high $\mathrm{Mg}$-calcite form by methanogenesis by $\mathrm{CO}_{2}$ reduction 
ACCEPTED MANUSCRIPT

below the sulphate/methane interface (SMI) and have isotope fractionation with $\delta^{13} \mathrm{C}$ values of up to +30\%o (Curtis, 1977; Greinert et al., 2001; Çağatay et al., 2001; Orphan et al., 2004; Naehr et al., 2007; Crémière et al., 2012). Such positive $\delta^{13} \mathrm{C}$ values are not found in the Marmara seafloor authigenic carbonates. Presence of microfossil shells and shell fragments (bivalve fragments, juvenile bivalves, foraminifera, coccolithophore) would have $\delta^{13} \mathrm{C}$ values in the range of $-5 \%$ to $0 \%$, and in general contribute ${ }^{13} \mathrm{C}$ to the $\delta^{13} \mathrm{C}$ values of the seafloor authigenic carbonate cement. Another source of the DIC pool would be the microbial oxidation of sedimentary organic matter and crude oil; one such source in the Sea of Marmara is the Holocene sapropelic sediments that have an average $\delta^{13} \mathrm{C}$ value of $-24.5 \%$ (Tolun et al., 2002).

Samples from Tekirdağ Basin (- 42.1\%o to -27.9\%o) show relatively narrower range of $\delta^{13} \mathrm{C}$ values than those from the Çınarcık (-46.4\% to $-29.6 \%$ ) and Central basins $(-47.6 \%$ o to $29.8 \%$ ). The $\delta^{13} \mathrm{C}$ values of all seafloor authigenic carbonates from the deep basins suggest that they are related to the anaerobic oxidation of biogenic and thermogenic methane. Some carbonate crust samples collected from the extensional boundary faults of the deep basins are relatively enriched in ${ }^{13} \mathrm{C}$ with $\delta^{13} \mathrm{C}$ values ranging from $\sim-30 \%$ to $-28 \%$, and appear to fall within the expected range of thermogenic methane sources (Fig. 11). Two such samples (1647-R1 and 1667-R3) are from the Tekirdağ Basin. Sample 1647-R1 is located in the western part of Tekirdağ Basin on the edge of a tension gash emitting a $\mathrm{CO}_{2}$ rich gas carrying mantle-derived He (Burnard et al., 2012). The relatively high $\delta^{13} \mathrm{C}$ value (-27.9\%o) of sample 1647-R1 thus probably reflects the isotopic composition of the gas, which could possibly combine mantle-sourced and thermogenic hydrocarbon components. Sample 1667-R3 (chimney) is from a carbonate chimney emitting brackish Marmara "Lake" waters in SE Tekirdağ Basin (Figs. 1B, 10; Zitter et al., 2008). Other samples with a possible thermogenic hydrocarbon component from the deep basins are 1661-R3 (eastern Central Basin) and 1659R1 (southern Çınarcık Basin). However, molecular and isotopic compositions of the sampled gases indicate a predominatly microbial methane source in the basinal sites including SE Tekirdağ Basin and southern Çınarcık Basin, with the molar percentage and $\delta^{13} \mathrm{C}$ values of methane ranging from 94.5 to $99.8 \%$ and -66.0 to $-52.2 \%$, respectively (Bourry et al., 2009; Ruffine et al, this issue b). The relatively ${ }^{13} \mathrm{C}$-enriched value of samples $1661-\mathrm{R} 3,1659-\mathrm{R} 1$, 1667-R3 are likely to be influenced by some contribution from ${ }^{13} \mathrm{C}$-enriched biogenic carbonates observed by the microscopic studies that consist of planktonic fossils 


\section{ACCEPTED MANUSCRIPT}

(foraminifera, coccoliths) and sand-silt size shell fragments of bivalve and calcified tube worms (Figs. 7, 8, 9).

The authigenic carbonate samples from the Western and Central highs have a range of $\delta^{13} \mathrm{C}$ values of between $-36.6 \%$ and $-13.7 \%$. With exception of two outlier values of $-36.6 \%$ (sample 1662-R3) and -35.4\% (sample DV02-CC02) from the Western High, $\delta^{13} \mathrm{C}$ values for the seven samples are restricted to a narrow range between $-24.9 \%$ and $-13.7 \%$ (Table 2, Fig. 11). The sampling sites of authigenic carbonate samples on the Western and Central highs are located on mud volcanoes and anticlines emitting thermogenic gas, which consists of methane and heavier hydrocarbon gases with the molar percentage and $\delta^{13} \mathrm{C}$ values of methane ranging from $87.6 \%$ to $98.8 \%$ and $-43.5 \%$ o to $-53.8 \%$, respectively (Bourry et al., 2009; Ruffine et al., this issue b). In addition, oil associated with high salinity basin fluids was present on the Western High mud volcano (Bourry et al., 2009; Tryon et al., 2010, 2012). The hydrocarbon gases sampled at this sites (Bourry et al., 2009) have similar isotopic signature with the natural gas produced from the Thrace Basin (Gürgey at al., 2005, 2009). The Western and Central highs are also the sites of mantle He, heavy hydrocarbon gas and oil. It can therefore be concluded that the carbonate crusts with $\delta^{13} \mathrm{C}$ values of $-36.6 \%$ to $-20 \%$ from the compressional highs strongly suggest that the main source of carbon is the anaerobic oxidation of thermogenic methane, with some contributions from degradation of organic matter and heavy hydrocarbons. Western High samples 1662-R3 and DV02-CC02 with relatively low $\delta^{13} \mathrm{C}$ values $(-35.5 \%$ and $-36.6 \%$ ) require no other additional source apart from the AOM reaction involving mainly thermogenic methane. Sample 1662-R3 is located on the mud volcano and sample DV02-CC02 about $5 \mathrm{~km}$ westward along the fault where no oil seepage is found (Fig. 1B). These samples consist mainly of aragonite and represent early stage authigenic cements.

Samples with $\delta^{13} \mathrm{C}$ values higher than -25\%o (DV02-CC03, 1662-R1, 1662-R4, 1664R2) require some admixture of heavy carbon $\left({ }^{13} \mathrm{C}\right)$ mainly from the oxidation of heavy hydrocarbons, methanogenesis reaction in the subsurface, or oxidation of gases from hydrate dissociation providing the DIC pool with ${ }^{13} \mathrm{C}$ (e.g., Bohrmann et al., 1998; Greinert et al., 2001; Orphan et al., 2004; Naehr et al., 2007; Bahr et al., 2010; Crémière et al., 2012, 2013). These processes are supported by a crude oil seep, gas hydrate presence and $4 \% \mathrm{CO}_{2}$ with positive $\delta^{13} \mathrm{C}$ values ( $+29 \%$ VPDB) from the mud volcanoes on the Western High (Bourry et al., 2009; Ruffine et al., this issue a), as well as $\delta^{13} \mathrm{C}$ values of up to $+14.2 \%$ of the subsurface carbonate nodules in two cores from the Western High, (Crémière et al., 2012, 2013). 


\section{ACCEPTED MANUSCRIPT}

Subsurface carbonate nodules in one of these core (MNT-KS27) containing gas hydrates consist mainly of high $\mathrm{Mg}$-calcite. With $\delta^{13} \mathrm{C}$ values of $-21.4 \%$ o to $+9.2 \%$ o these nodules are related to diffusive upward flux of hydrocarbons generated by gas hydrate destabilization (Crémière et al., 2013), as proposed elsewhere for other hydrate-bearing settings (Bahr et al., 2010; Bohrmann et al., 1998; Greinert et al., 2001).

The minor carbonate associated with the barite sample (1666-R1) is aragonite and has $\delta^{13} \mathrm{C}$ value of $-0.6 \%$ (Table 2 ). On the other hand, the two corals from the Çınarcik and Central basins have the same $\delta^{13} \mathrm{C}$ value of $-4.6 \%$, which likely represents $\delta^{13} \mathrm{C}$ value of the bottom seawater DIC values.

Oxygen isotopic composition of authigenic carbonate crusts can be used to reconstruct the precipitation temperature or the isotopic composition of fluids, assuming thermodynamic equilibrium (e.g., Kim and O'Neal, 1997). In the case of the Marmara seafloor carbonate crusts, using the constant bottom water temperature of $14.5^{\circ} \mathrm{C}$ and the oxygen isotopic ratio of $1.58 \pm 0.03 \%$ o $(1 \sigma) \mathrm{V}$-SMOW (Rank et al., 1999), the $\delta^{18} \mathrm{O}$ values of aragonite, high- $\mathrm{Mg}$ calcite and dolomite precipitating in equilibrium from the Marmara bottom water would have 2.78\% V-PDB, 2.34\% V-PDB and 5.81\%o V-PDB, respectively (Crémière et al., 2012). These theoretical $\delta^{18} \mathrm{O}$ values are broadly compatible with the $\delta^{18} \mathrm{O}$ values of most Marmara seafloor authigenic carbonate samples, ranging between 1.3\%o and 3.8\% V-PDB (Table 2, Fig. 11). However, the Marmara carbonate crust $\delta^{18} \mathrm{O}$ values show no apparent relationship with the mineral composition; the ranges for aragonite-rich, $\mathrm{Mg}$-calcite and dolomite-rich samples are 1.6\%o - 3.3\%o (mean: $2.7 \%$ o, $n=13$ ), 1.8\%o - 3.8\%o (mean: $2.6 \%$, $n=4$ ) and 2.5\%o$2.9 \%$ o $(n=2)$, respectively.

The relatively low $\delta^{18} \mathrm{O}$ values $(0.5-2.3 \%$ V-PDB) of the Marmara authigenic carbonate crusts suggest contribution of brackish Marmara "Lake" waters whereas heavy values (2.8-3.8\%) are likely due to admixture of deep formation waters from the Thrace Basin or waters from the destabilization of gas hydrates (Naehr et al., 2007; Bahr et al., 2010; Crémière et al., 2012). The lowest $\delta^{18} \mathrm{O}$ value of $0.5 \%$ is found in one carbonate crust sample (1649-R1) from the western part of the Central Basin (Table 2, Fig. 1C). The next lowest value of $1.3 \%$ are measured in two authigenic carbonate crust samples (DV04-CC01 and 1667-R3) from the chimney "Jack the Smoker" and its near vicinity in SE Tekirdağ Basin (Fig. 1B). These sites in the Central and Tekirdağ basins emit brackish Marmara "Lake" waters. With a $\delta^{18} \mathrm{O}$ value of $-10.2 \%$ V-SMOW (Aloisi et al., 2015), the late Pleistocene Marmara "Lake" water could precipitate carbonate minerals with $\delta^{18} \mathrm{O}$ values of $-9.2 \%$ PDB 
to $-7.2 \% \mathrm{PDB}$ at $14.5^{\circ} \mathrm{C}$, and thus contribute to the low values in the carbonate crusts. Porewater analysis from different parts of the Sea of Marmara by Tryon et al. (2010) suggest signatures of silicate diagenetic reactions both in the highly saline formation waters seeping from the mud volcanoes on the western high and in less saline water emitted on the Central High and in the deep basins. Such waters involved in silicate diagenesis, including clay dehydration water, could thus contribute to the heavy oxygen isotope values of authigenic carbonates from the western high mud volcano, as well as those from some other seep sites, notably on the Central high, in the Central Basin and in SE Çınarcık Basin.

\subsection{Formation of the authigenic carbonates and black reduced sediments}

The seafloor authigenic carbonates in the Sea of Marmara occur as pavements, crusts, slabs, mounds and chimneys along the active faults of NAFS, and are commonly associated with black reduced sediment patches and often with active hydrocarbon gas emissions. In such authigenic carbonate sites with high methane flux, the SMI occurs at or close to the seafloor, whereas elsewhere in the Sea of Marmara, the same interface is located at between 2 $\mathrm{m}$ and $7.5 \mathrm{~m}$ below the seafloor (Çağatay et al., 2004; Halbach et al., 2004; Tryon et al., 2010). These features, together with very light stable carbon isotope values $\left(\delta^{13} \mathrm{C}=-29.8\right.$ to $47.6 \%$ ) and the presence of ${ }^{13} \mathrm{C}$-depleted archaeal and bacterial biomarkers (sulfate reducing bacteria and ANME-2 archaea) characteristic of AOM (Chevalier et al., 2011; Akhoudas et al., this issue; Teichert et al., this issue), indicates that the AOM on the active faults is the major process responsible for the carbonate precipitation. With a high upward methane flux, this reaction provides the necessary $\mathrm{HCO}_{3}{ }^{-}$and $\mathrm{HS}^{-}$ions for the precipitation of the authigenic carbonate crusts and Fe-sulphides in the black reduced sediments at or close to the seafloor (e.g., Greinert et al., 2002; Naehr et al., 2007; Peketi et al., 2012; Crémière et al., 2013; Pierre et al., 2012).

Many carbonate crust samples contain pyrite grains and framboids and Fe-oxyhydroxide veins, and are characterized by higher than $0.5 \mathrm{wt} \% \mathrm{~S}, 1 \mathrm{wt} \% \mathrm{Fe}$ and $20 \mu \mathrm{g} / \mathrm{g}$ Mo (Table 2). The presence of pyrite in the carbonate crusts suggests deposition under reducing conditions. Barium in the Western High barite precipitates and the carbonate crust samples from the eastern edge of the Central Basin with Ba values higher than $400 \mu \mathrm{g} / \mathrm{g}$ are sourced from dissolution of authigenic (bio) barite below the SMI, which diffused and/or advected upwards to deposit at or near seafloor by reacting with the seawater $\mathrm{SO}_{4}^{-2}$ (Naehr et al., 2007; Tryon et al., 2010, 2012). 


\section{ACCEPTED MANUSCRIPT}

Fracturing and fine fracture filling by carbonate and pyrite suggest later fault activity and/or associated fluid activity. However, black to dark brown Fe-Mn staining on the surface of some crusts together with common presence of solution pores indicate that these carbonate crusts were later oxidized and dissolved by the acidic conditions created by the pyrite oxidation (Crémière et al., 2010). Another possible scenario for carbonate dissolution is the aerobic oxidation of methane and hydrogen sulphide, which was suggested for Eastern Mediterranean Sea mud volcano carbonate crust (Himmler et al., 2011). Minor amount of well-developed gypsum observed in such carbonate crusts are formed by reaction of $\mathrm{Ca}^{2+}$ with the $\mathrm{SO}_{4}{ }^{-2}$ produced by pyrite oxidation (Lin et al., 2016; Pierre, 2017).

\subsection{Temporal evolution of authigenic carbonates}

U-Th ages of five seafloor authigenic carbonate cements and one coral sample analysed in this study range between $0.11 \mathrm{ka} \mathrm{BP}$ and $9.61 \mathrm{ka} \mathrm{BP}$ (Table 4). One sample (DV04-CC01) is characterized by low $\delta^{234} \mathrm{U}$ initial value $(<130)$. This may indicate strong diagenesis as suggested by the presence of pyrite and gypsum, so there might be some uncertainty associated with the corresponding U-Th age. The other Marmara Sea samples have $\delta^{234} U$ around 140-145 permil, hence similar to seawater values (146.6 $\pm 2.5 \%$; Robinson et al., 2004).

The age data so far obtained from the seafloor carbonate crusts of the Sea of Marmara by this study and Crémière et al. (2013) are too few (i.e., 14 U-Th dates) to discuss their detailed temporal evolution and relation to the paleoenvironmental changes, and especially to the seimotectonically triggered fluid activity. Nevertheless, it is possible to make some assumptions about the temporal-environmental evolution of the seafloor authigenic carbonates using the available U-Th data.

The U-Th ages of the 14 seafloor authigenic carbonate samples show some gaps during 4-6 ka BP and 7-9 ka BP intervals (Table 2, Fig. 10). Six samples have ages less than or nearly equal to $1 \mathrm{ka}$ (Table 2; Fig. 10), in conformity with being exposed on the seafloor or under only a few centimetre sediment cover. The occurrence of older authigenic carbonates being exposed on the seafloor, can be explained by non-deposition due to winnowing by bottom currents and/or continuous fluid emission as previously suggested by Crémière et al. (2013). The oldest two samples (1661-R4 and 1664-R5) from eastern Central Basin with ages of $9.61 \mathrm{ka} \mathrm{BP}$ and $9.14 \mathrm{ka} \mathrm{BP}$ are covered by a few mm-thick veneer of ochre, umber to black Fe-Mn-oxyhydroxides, which conforms with their old age. These two samples, representing a banded seafloor carbonate pavement and the top of the nearby $2 \mathrm{~m}$-high carbonate mound are 


\section{ACCEPTED MANUSCRIPT}

likely formed by the large methane release from gas hydrates dissociation in the Sea of Marmara during 12.7 to 9.5 cal ka BP (Ménot and Bard, 2010). This event was most likely related to global warming because the Marmara bottom water, consisting essentially of the Mediterranean surface water, was subjected to temperature increase after the late glacial, as discussed by Ménot and Bard (2010). Another possible mechanism for the gas hydrate dissociation would be the warm fluids ascending through the faults but no hydrothermal fluids have been detected so far on the seafloor during the various cruises carried out since the 1999 İzmit earthquake.

The gas hydrate dissociation scenario is not supported by the relatively light $\delta^{18} \mathrm{O}$ values $(2.0 \%, 2.2 \%)$ of the samples but this may be due to the admixture of light $\delta^{18} \mathrm{O}$ sources such as the ambient bottom waters and the Marmara lacustrine waters. The same methane release event is also recorded in buried authigenic carbonate nodules analysed by Crémière et al. (2013) in two cores from the Western High, which were estimated to have formed by the $\mathrm{AOM}$ reaction at a few $\mathrm{cm}$ to $40 \mathrm{~cm}$ below the seafloor. The ages of 16 buried carbonate nodules range between $6.7 \mathrm{ka} \mathrm{BP}$ and $13.6 \mathrm{ka} \mathrm{BP}$, with most of the samples gathering between 9 and $10 \mathrm{ka}$. The 9-10 ka period of main authigenic carbonate formation is well after the reconnection of the Sea of Marmara with the Mediterranean at 14-12 ka BP (Çağatay et al., 2000, 2015, Vidal et al., 2010). Crémière et al. (2013) related the formation of the carbonate nodules to the anoxic period in the Sea of Marmara, which led to the deposition of the Holocene Marmara sapropel (Çağatay et al., 2000, 2015; Tolun et al., 2002). However, the main authigenic carbonate formation during 9-10 ka in the Sea of Marmara overlaps but does not completely match with the recently determined age of 12.3 - 5.7 calkyr BP for the Holocene Marmara sapropel (Çağatay et al., 2015). Moreover, the sapropel was deposited mainly under suboxic and dysoxic conditions, rather than anoxic conditions, as indicated by the presence of benthic foraminifera (Çağatay et al., 2000, 2009). These facts, together with the variable $\delta^{13} \mathrm{C}$ values of the buried authigenic carbonate nodules between $-21.3 \%$ and $+14.2 \%$ showing changes in the contribution of different sources, all suggest that different processes such as seismo-tectonics and gas hydrates destabilization due to global warming might have played important roles in the formation of the authigenic carbonate crusts (e.g., Reagan et al., 2011; Marín-Moreno et al., 2013; Crémière et al., 2016).

The fact that there were gas flares with fire balls during the 1999 İzmit earthquake and the intense gas emissions in the water column following the event (Alpar, 1999; Halbach et al., 2004; Kuşcu et al., 2005), which decreased about ten years after the earthquake, strongly 


\section{ACCEPTED MANUSCRIPT}

suggests a link between seismic and fluid activities in the Sea of Marmara. Similar relationship has been observed elsewhere in offshore areas such as North California, Costa Rica, Okhotsk Sea and Arabian Sea (e.g., Field and Jennings, 1987; Mau et al., 2007; Obzhirov et al., 2004, Fischer et al., 2013). Methane-related seafloor and buried authigenic carbonates could therefore provide a valuable archive for paleo-seismic activity along the individual fault segments of the NAFS.

The U/Th ages of authigenic carbonates along the NAFS in the Sea of Marmara can not be specifically matched with the historical earthquakes (e.g., Ambraseys and Finkel, C.F., 1995; Ambraseys, 2002). This is mainly because of the insufficient U/Th age data and inadequate sampling strategy without consideration of textural details. Such a study would require detailed sampling and $U / T h$ dating of the authigenic carbonates at specific sites, with a careful consideration to the paragenetic relationships of the different carbonate precipitation phases and fine textural features, such as the layering and cross-cutting relationships. In this regard, a high-resolution multi-proxy study carried out by Teichert et al. (this isue) in the southeast Çınarcık Basin provides a promising example for the use of authigenic carbonates as archives of past seismic activity.

\section{Summary and conclusions}

Widespread methane-related seafloor authigenic carbonate crusts occur as pavements, mounds and chimneys along the NAFS in the Sea of Marmara, which are often associated with patches of reduced (Fe-sulphide-rich) sediments. In the deep basins, the carbonate crusts and the black reduced sediments are located on the hydrocarbon-rich fluid emissions from the active faults, whereas on the compressional Western and Central highs they are observed on the mud volcanoes and anticlines nearby the active fault. They were precipitated at or close to the seafloor under bottom water conditions similar to those of the present day.

The textures and structures of the carbonate crusts are variable with sinter-like porous, botryoidal and sugary-granular textures, and consists mainly of carbonate cemented bivalve shells and shell fragments, serpulid tubes, fibrous and filamentous microbial organic matter and rarely pebbles. The authigenic cements is composed mainly of aragonite in most sites, except for some samples from Tekirdağ and Central basins, in which major amounts of high Mg-calcite are present.

The $\delta^{13} \mathrm{C}$ values of the seafloor authigenic carbonates range between $-47.62 \%$ and $13.65 \%$, which together with their close association with reduced sediments, indicate a DIC 


\section{ACCEPTED MANUSCRIPT}

pool supplied mainly by the anaerobic oxidation of microbial or thermogenic methane. Relatively heavy carbon isotope values $(-24.9 \%$ to $-13.7 \%$ ) of authigenic carbonates from the compressional Western and Central highs suggest a DIC source mainly of thermogenic methane with some contribution from the abiogenic crustal-sourced methane and the biodegradation of heavy hydrocarbons. These conclusions are in agreement with the presence of thermogenic gas, oil seeps and shallow gas hydrates on the Western High mud volcano, all having compositional and isotope signatures similar to those of the Thrace Basin.

Formation of the carbonate crusts and the black reduced sediments is explained by high methane flux that results in the AOM reaction taking place at or near the seafloor. The AOM provides the high alkalinity $\left(\mathrm{HCO}_{3}{ }^{-}\right)$and $\mathrm{HS}^{-}$ions, necessary for the formation of the authigenic carbonates and Fe-sulphides of the black reduced sediments.

Measured $\delta^{18} \mathrm{O}$ values of the Sea of Marmara carbonate crusts show no clear relationship with the mineral composition, but about $50 \%$ of samples with values between $+2.0 \% 0^{-}+2.8 \%$ o V-PDB are broadly compatible with deposition from the Sea of Marmara bottom waters of Mediterranean origin. However, relatively low $\delta^{18} \mathrm{O}$ values $(0.5-2.3 \%$ V-PDB) of the Marmara carbonate crusts mainly in the deep basin sites with predoninatly of aragonite composition result from contribution of brackish Marmara "Lake" waters, whereas higher values $(+2.6 \%$ o to $+3.4 \%$ o $-\mathrm{PDB}$, average $=+3.0 \%$, $n=9)$ at mainly the compressional highs with significant enrichment of high $\mathrm{Mg}$-calcite composition are likely due to the admixture of deep Thrace Basin formation waters or contribution of water from the destabilization of gas hydrates.

U-Th ages of five seafloor authigenic carbonate cements range between $0.11 \mathrm{ka} \mathrm{BP}$ and $9.61 \mathrm{ka} \mathrm{BP}$, with most of the samples dating less than $1 \mathrm{ka} \mathrm{BP}$. Two samples from eastern most part of the Central basin date back to 9-10 ka BP and are likely related to the event of large methane release in the sea of Marmara during 12.7 to 9.5 calkyr BP.

Various lines of evidence suggest a strong association between the seismic and fluid activities in the Sea of Marmara, that make the authigenic carbonates an important archive of paleo-earthquakes. Therefore, a systematic study involving U-Th dating together with stable isotope and biomarker analyses of the seafloor and buried carbonate crusts and nodules along the various segments of NAFS is recommended. Such a study, taking into consideration of the paragenesis of different carbonate precipitation phases during the sampling, would contribute to the understanding of the relations between seismic and fluid activities and the temporal 


\section{ACCEPTED MANUSCRIPT}

evolution of the processes leading to the formation of the carbonate crusts, chimneys and mounds.

\section{Acknowledgments:}

The authors would like to thank the scientific teams of Marnaut and Marsite cruises, and captains and crews of RVs L'Atalante and the Pourquoi pas? as well as the Nautile manned submersible and ROV Victor 6000. Dr. Nazlı Olgun Kiyak helped with sampling of the srusts onboard Pouquoi Pas? Emmanuel Ponzevera and Alexis De Prunelé of Ifrmer are thanked for the U-Th analyses by MC-ICPMS, Prof. Gültekin Göller and Engineer Hüseyin Sezer of Metallurgical Engineering Department at ITU for the use of SEM facilities and Asen Sabuncu of EMCOL for preparing the maps. Graduate student scholarship to GY and funding of laboratory studies were provided by TÜBİTAK under project $115 \mathrm{Y} 471$, granted to MNC. Some funds for additional analyses were also provided by ITU Scientific Research Unit, MSC thesis support program under project number 39357. The Marsite crusie was co-funded by the EC FP7 project MARSITE "Long-term monitoring experiment in geologically active regions of Europe prone to natural hazards: the Supersite concept" under the call ENV.2012.6.4-2 and by the "Laboratoire d'Excellence" LabexMER (ANR-10-LABX-19) through the projects called MicroGaMa and MISS Marmara, and by a grant from the French government under the program "Investissements d'Avenir". The manuscript benefited greatly from the suggestions and criticisms of the two anonymous DSR reviewers.

\section{References}

Akhoudas, C., Chevalier, N., Blanc-Valleron, M-M, Klein, V., Mendez, M., Demange, J., Dalliah, S., Rommevaux, V., Boudouma, O., Pierre1, C., Ruffine, L., This issue. Methane-derived stromatolitic formation at cold seeps in the western basin of the Sea of Marmara: Evidence from a mineralogical, isotopic and molecular geochemical approach. Deep-Sea Research Part II: Topical Studies in Oceanography.

Aksoy, M. E., Meghraoui, M., Vallee, M., Çakir, Z., 2010. Rupture characteristics of the AD 1912 Murefte (Ganos) earthquake segment of the North Anatolian fault (western Turkey). Geology 38, 991-994, doi:10.1130/G31447.1.

Ambraseys, N.N., 2002. The seismic activity of the Marmara Sea region over the last 2000 years. Bulletin of the Seismological Society of America 92, 1-18.

Ambraseys, N.N., Finkel, C.F., 1995. The Seismicity of Turkey and Adjacent Areas-A Historical Review. Eren Yayıncılık, İstanbul, pp. 1500-1800. 240 pp.

Aloisi, G., Pierre, C., Rouchy, J.-M., Foucher, J.-P., Woodside, J., 2000. Methane-Related Authigenic Carbonates of Eastern Mediterranean Sea Mud Volcanoes and Their 


\section{ACCEPTED MANUSCRIPT}

Possible Relation to Gas Hydrate Destabilisation. Earth and Planetary Science Letters 184 (1), 321-338.

Aloisi, G., I. Bouloubassi, S.K. Heijs, R.D. Pancost, C.Pierre, J.S. Sinninghe Damste, J.C. Gottschal, L.J. Forney,, J.-M. Rouchy 2002. $\mathrm{CH}_{4}$-consuming microorganisms and the formation of carbonate crusts at cold seeps. Earth and Planetary Science Letters 203 (1), 195-203.

Aloisi, G., Soulet, G., Henry, P., Wallmann, K., Sauvestre, R., Vallet-Coulomb, C., Bard, E., 2015. Freshening of the Marmara Sea prior to its post-glacial reconnection to the Mediterranean Sea. Earth and Planetary Science Letters 413, 176-185. doi:10.1016/j.eps1.2014.12.052.

Alpar, B., 1999. Underwater signatures of the Kocaeli earthquake of 17 August 1999 in Turkey. Turkish Journal of Marine Sciences 5, 111-130.

Ambraseys, N., 2002. Th e seismic activity of the Marmara Sea region over the last 2000 years. Bulletin of the Seismological Society of America 92, 1-18.

Artüz, M.L., 2006. Investigations on beam-trawl Fishery for Deep Sea Pink Shrimp Parapenaeus longirostris (Lucas, 1846) in the Sea of Marmara. Ecology Natura, 65-67.

Armijo, R., Pondard, N., Meyer, B., Ucarkus, G., de Lepinay, B.M., Malavieille, J., Dominguez, S., Gustcher, M.-A., Schmidt, S., Beck, C., Çağatay, N., Cakir, Z., Imren, C., Eris, K., Natalin, B., Ozalaybey, S., Tolun, L., Lefevre, I., Seeber, L., Gasperini, L., Rangin, C., Emre, O., Sarikavak, K., 2005. Submarine fault scarps in the Sea of Marmara pull-apart (North Anatolian Fault): implications for seismic hazard in Istanbul. Geochemistry, Geophysics, Geosystems 6, Q06009.

Barka, A., Akyuz, H.S., Altunel, E., Sunal, G., Cakir, Z., Dikbas, A., Yerli, B., Armijo, R., Meyer, B., de Chabalier, J.B., Rockwell, T., Dolan, J.R., Hartleb, R., Dawson, T., Christofferson, S., Tucker, A., Fumal, T., Langridge, R., Stenner,H., Lettis, W., Bachhuber, J., Page,W., 2002. The surface rupture and slip distribution of the 17 August 1999 Izmit earthquake (M 7.4),North Anatolian Fault. Bulletin of the Seismological Society of America 92, 43-60.

Bayon, G., Dupré S., Ponzevera, E., Etoubleau, J., Chéron, S., Pierre, C., Mascle J., Boetius A., de Lange G., 2013. Formation of carbonate chimneys in the Mediterranean Sea linked to deep-water oxygen depletion. Nature Geosci. 6, 755-760.

Bayon, G., Henderson, G.M., Etoubleau, J., Caprais, J.-C., Ruffine, L., Marsset, T., Dennielou, B., Cauquil, E., Voisset, M. Sultan, N., 2015. U-Th isotope constraints on gas hydrate and pockmark dynamics at the Niger Delta margin. Mar. Geol. 370, 87-98.

Bayrakc1, G., Laigle, M., Bécel, A., Hirn, A., Taymaz, T., Yolsal-Cevikbilen, S., SEISMARMARA team., 2013. "3-D sediment-basement tomography of the Northern Marmara trough by a dense OBS network at the nodes of a grid of controlled source profiles along the North Anatolian fault". Geophys. J. Int. 194, 1335-1357.

Beck, C., Mercier de Lepinay, B., Schneider, J.-L., Cremer, M., Çağatay, N., Wendenbaum, E., Boutareaud, S., Menot- Combes, G., Schmidt, S., Weber, O., Eriş, K., Armijo, R., Meyer, B., Pondard, N., Gutcher, M.-A., Turon, J.L., Labeyrie, L., Cortijo, E., Gallet, Y., Bouquerel, H., Görür, N., Gervais, A., Castera, M.H., Londeix, L., de Resseguier, A. and Jaouen, A., 2007. Late Quaternary co-seismic sedimentation in the Sea of Marmara's deep basins. Sedimentary Geology 199 (1-2), 65-89. 


\section{ACCEPTED MANUSCRIPT}

Bergquist, D.C., Ward, T., Cordes, E.E., McNelis, T., Howlett, S., Koisoff, R., Hourdez, S., Carney, R., and Fisher, C.R., 2003. Community structure of vestimentiferan-generated habitat islands from Gulf of Mexico cold seeps. Journal of Experimental Marine Biology and Ecology 289, 197-222.

Bergquist, D.C., Eckner, J.T., Urcuyo, I. A., Cordes, E.E., Hourdez, S., Macko, S. A., and Fisher, C. R., 2007. A local hydrothermal vent food web: Application of stable isotopes to a complex community. Mar. Ecol. Prog. Ser. 330, 49-65, doi:10.3354/meps330049.

Beşiktepe, S.T., Sur, H.I., Özsoy, E., Latif, M.A., Oğuz, T., Ünlüata, Ü., 1994. The circulation and hydrography of the MarmaraSea. Prog.Oceanogr. 34(4), 285-334.

Bécel, A., Laigle, M., de Voogd, B., Hirn, A., Taymaz, T., Yolsal-Cevikbilen, S., and Shimamura, H., 2010. North Marmara Trough architecture of basin infill, basement and faults, from PSDM reflection and OBS refraction seismics. Tectonophysics 490(1-2), $1-14$.

Birgel, D., Feng, D., Roberts, H.H., Peckmann, J., 2011. Changing redox conditions at cold seeps as revealed by authigenic carbonates from Alaminos Canyon, northern Gulf of Mexico. Chem. Geol. 285, 82e96.

Boetius, A., Ravenschlag, K., Schubert, C.J., Rickert, D., Widdel, F., Gieseke, A., Amann, R., Jorgenson, B.B., Witte, U., and Pfannkuche, O., 2000. A marine microbial consortium appearantly mediating anaerobic oxidation of methane. Nature 407 (6804): 623-626.

Bohrmann, G., Greinert, J., Suess, E., Torres, M., 1998. Authigenic carbonates from the Cascadia subduction zone and their relation to gas hydrate stability. Geology 7, $647-$ 650 .

Burnard, P., Bourlange, S., Henry, P., Geli, L., Tryon, M.D., Natal'in, B., Sengör, A.M.C., Özeren, M.S., and Çağatay, M.N., 2012. Constraints on fluid origins and migration velocities along the Marmara Main Fault (Sea of Marmara, Turkey) using helium isotopes. Earth and Planetary Science Letters 341-344, 68-78.

Borowski, W.S., Paull, C.K., Ussler, W., 1996. Marine pore-water sulfate profiles indicate in situ methane flux from underlying gas hydrate. Geology 24(7): 655-658.

Bourry, C., Chazallon, B., Charlou, J.L., Donval, J.P., Ruffine, L., Henry, P., Geli, L., Cagatay, M.N., Inan, S.,Moreau, M., 2009. Free gas and gas hydrates from the Sea of Marmara, Turkey: chemical and structural characterization. Chemical Geology 264, 197-206.

Bureau Veritas Minerals, 2015. Schedule of Services and Fees (CDN). 42 pages. https://www.bureauveritas.com

Burton, E.A., Walter, L.M., 1987. Relative precipitation rates of aragonite and Mg calcite from seawater: Temperature or carbonate ion control? Geology 15, 111-114. doi: 10.1130/0091-7613(1987)15<111:rproaa $>2.0 . c 0 ; 2$.

Çağatay, M.N., Algan, O., Sakinç, M., Eastoe, C.J., Egesel, L., Balkis, N., Ongan, D., Caner, H., 1999. Mid-late Holocene sapropelic sediment unit from the southern Marmara sea shelf and its paleoceanographic significance. Quaternary Science Reviews 18, 531-540.

Çağatay, M.N., Borowski, W.S., Ternois, Y.G., 2001. Factors affecting the diagenesis of Quaternary sediments at ODP Leg 172 sites in western North Atlantic: evidence from pore water and sediment geochemistry. Chemical Geology 175, 467-484. 


\section{ACCEPTED MANUSCRIPT}

Çağatay, M.N., Eriş, K., Ryan, W.B.F., Sancar, Ü., Polonia, A., Akçer, S., Biltekin, D., Gasperini, L., Görür, N., Lericolais, G., Bard, E., 2009. Late Pleistocene-Holocene evolution of the northern shelf of the Sea of Marmara. Mar Geol 265, 87-100.

Çağatay, M.N., Görür, N., Algan, O., Eastoe, C., Tchapalyga, A., Ongan, D., Kuhn, T., Kuscu, I., 2000. Late Glacial- Holocene paleooceanography of the Sea of Marmara: Timing of connections with the Mediterranean and the Black seas. Mar. Geol. 167, 191206.

Çağatay, M.N., Özcan, M., Güngör, E., 2004. Pore water and sediment geochemistry in the Marmara Sea (Turkey): early diagenesis and diffusive fluxes. Geochemistry: Exploration, Environment, Analysis (Geol. Soc. London) 4, 213-225.

Campbell, K.A., 2006. Hydrocarbon seep and hydrothermal vent paleoenvironments and paleontology: Past developments and future research directions. Palaeogeography, Palaeoclimatology, Palaeoecology 232, 362-407.

Charlou, J.L., Donval, J.P., Zitter, T., Roy, N., JeanBaptiste, P., Foucher, J.-P., Woodside, J., and The MEDINAUT Scientific Party, 2003. Evidence of methane venting and geochemistry of brines on mud volcanoes of the eastern Mediterranean Sea. Deep-Sea Research Part I 50, 941-958.

Chevalier, N., Bouloubassi, I., Birgel, D., Crémière, A., Taphanel, M.-H., Pierre, C., 2011. Authigenic carbonates at cold seeps in the Marmara Sea (Turkey): a lipid biomarker and stable carbon and oxygen isotope investigation. Marine Geology 288, 112-121.

Crémière, A., Lepland, A., Chand, S., Sahy, D., Condon, D.J., Noble, S.R., Martma, T., Thorsnes, T., Sauer, S., Brunstad, H., 2016. Timescales of methane seepage on the Norwegian margin following collapse of the Scandinavian Ice Sheet. Nature Communications, 7, 11509, DOI:10.1038/ncomms 11509.

Crémière, A., Pierre, C., Valleron, M.M., Zitter, T., Çağatay, M.N., and Henry, P., 2012. Methane-derived authigenic carbonates along the North Anatolian fault system in the Sea of Marmara (Turkey). Deep-Sea Research I 66, 114-130.

Crémière, A., Bayon, G., Ponzevera, E., Pierre, C., 2013. Paleo-environmental controls on cold seep carbonate authigenesis in the Sea of Marmara. Earth and Planetary Science Letters 376, 200-211.

Curtis, C.D., 1977. Sedimentary geochemistry: environments and processes dominated by involvement of an aquaeous phase. Philos. Trans. R. Soc. London, Ser. A 286, 353-372.

De Choudens-Sánchez, V., González, L.A., 2009. Calcite and aragonite precipitation under controlled instantaneous supersaturation: elucidating the role of $\mathrm{CaCO} 3$ saturation state and $\mathrm{Mg} / \mathrm{Ca}$ ration on calcium carbonate polymorphism. J Sediment Res 79, 363- 376.

Dupré S., Scalabrin, C., Grall, C., Augustin, J-M., Henry, P., Görür, N., Şengör, A. M. C., Çağatay, M.N., and Géli, L., 2015. Tectonic and sedimentary controls for widespread gas emissions in the Sea of Marmara, Results from systematic, ship-borne multibeam echosounder water column imageries. Journal of Geophysical Research: Solid Earth 04/2015; DOI: 10.1002/2014JB01161794.

Field, M.E., Jennings, A.E., 1987. Seafloor gas seeps triggered by a northern California earthquake. Marine Geology 77, 39-51.

Fischer, D., Mogollón, J. M., Strasser, M., Pape, T., Bohrmann, G., Fekete, N., Spiess, V., Kasten, S., 2013. Subduction zone earthquake as potential trigger of submarine hydrocarbon seepage. Nature Geoscience 6, 647-651. doi:10.1038/ngeo1886. 


\section{ACCEPTED MANUSCRIPT}

Geli, L., Henry, P., Zitter, T., Dupré, S., Tryon, M., Çağatay, M.N., Mercier de Lépinay, B., Le Pichon, X., Sengor, A.M.C., Görur, N., Natalin, B., Uçarkus, G., Volker, D., Gasperini, L., Burnard, P., Bourlange, S., and The MARNAUT Scientific Party, 2008. Gas emissions and active tectonics within the submerged section of the North Anatolian Fault zone in the Sea of Marmara. Earth and Planetary Science Letters 274, 34-39.

Görür, N., Okay, A.I., 1996. Fore-arc origin for the Thrace basin. Geol. Rundsch vol. 85, pp. 662-668.

Görür, N., Elbek, Ş., 2013. Tectonic events responsible for shaping the Sea of Marmara and its surrounding region. Geodin Acta. doi:1 0.1080/09853111.2013.859346.

Görür, N., Elbek, Ş., 2014. Tectonic events responsible for shaping the Sea of Marmara and its surrounding region. Geodinamica Acta, http://dx.doi.org/ 10.1080/09853111.2013.859346.

Goldsmith, J.R., Graf, D.L., Heard, H.C.,1961. Lattice constants of the calcium-magnesium carbonates. American Mineralogist 46, 453-457.

Greinert, J., Bohrmann, J.G., Suess, E., 2001. Gas hydrate-associated carbonates and methane-venting at Hydrate Ridge: classification, distribution, and origin of authigenic lithologies. In: Paull, C.K., Dillon, W.P. (Eds.), Natural Gas Hydrates: Occurrence, Distribution, and Detection, Geophysical Monograph vol. 124. American Geophysical Union pp. $87-98$.

Gürgey, K., Philp, R., Clayton, C., Emiroğlu, H., Siyako, M., 2005. Geochemical and isotopic approach to maturity/source/mixing estimations for natural gas and associated condensates in the Thrace Basin, NW Turkey. Appl. Geochem. 20, 2017-2037.

Gürgey, K., 2009. Geochemical overview and undiscovered gas resources generated from Hamitabat petroleum system in the Thrace Basin, Turkey. Mar.Pet. Geol. 26, 12401254.

Halbach, P., and the Scientific Party, 2000. Report and preliminary results of Meteor Cruise M44/1, in Östliches Mittelmeer-Nördliches Rotes Meer 1999, Cruise No. 44, 22 January-16 May 1999. METEOR-Berichte, edited by J. Pätzold et al., pp. 31-58, Univ. Hamburg, Hamburg, Germany.

Halbach, P., Holzbecher, E., Reichel, T., Moche, R., 2004. Migration of the sulphate-methane reaction zone in marine sediments of the Sea of Marmara-can this mechanism be tectonically induced? Chemical Geology 205, 73-82.

Henry, P., Şengör, A.M.C., Çağatay, M.N., 2007. Marnaut Cruise Report. 70 p. http://p.f.henry.free.fr/marmara/marnaut_public/marnaut_final_reports/MARNAUT_rep ort.pdf. http://dx.doi.org/10.17600/7010070.

Himmler, T., Brinkmann, F., Bohrmann, G. and Peckmann, J., 2011, Corrosion patterns of seep-carbonates from the eastern Mediterranean Sea. Terra Nova, 23: 206-212. doi:10.1111/j.1365-3121.2011.01000.x.

Kennicutt, M.C., Brooks, J.M., Bidigare, R.R., Fay, R.R., Wade, T.L., and McDonald, T.J., 1985. Vent-type taxa in a hydrocarbon seep region on the Louisiana slope. Nature 317, 351-353.

Kim, S.-T., O’Neil, J. R., 1997. Equilibrium and nonequilibrium oxygen isotope effects in synthetic carbonates. Geochim. Cosmochim. Acta 61, 3461-3475. 
Kuşçu, İ., Okamura, M., Matsuoka, H., Gökaşan, E., Awata, Y., Tur, H., Şİmşek, M. \& Keçer, M., 2005. Seafloor gas seeps and sediment failures triggered by the August 17, 1999 earthquake in the Eastern part of the Gulf of İzmit, Sea of Marmara, NW Turkey. Marine Geology 215, 193-214.

Le Pichon, X., Şengör, A.M.C., Demirbağ, E., Rangin, C., İmren, C., Armijo, R., Görür, N., Çağatay, N., Mercier De Lépinay, B., Meyer, B., Saatçilar, R., Tok, B., 2001. The active main Marmara fault. Earth Planetary Science Letters 192, 595-616.

Le Pichon, X., C. Şengör, J. Kende, C. İmren, P. Henry, C. Grall, and H. Karabulut, 2015. Propagation of a strike slip plate boundary within an extensional environment: the westward propagation of the North Anatolian Fault. Canadian Journal of Earth Sciences, 10.1139/cjes-2015-0129.

Levin, L.A., Mendoza, G., 2007. Community structure and nutrition of deep methane seep macroinfauna from the Aleutian margin and Florida Escarpment, Gulf of Mexico. Marine Ecology 28, 131-151.

Ludwig K.R., 2008. Using Isoplot/Ex, Version 3.70. A geochronological toolkit for Microsoft Excel: Berkeley Geochronology Ctr. Spec. Pub. 4.

Lin, Z.Y., Sun, X.M., Peckmann, J., Lu, Y., Xu, L., Strauss, H., Zhou, H.Y., Gong, J.L., Lu, H.F., Teichert, B.M.A., 2016. How sulfate-driven anaerobic oxidation of methane affects the sulfur isotopic composition of pyrite: A SIMS study from the South China Sea. Chem. Geol. 440, 26-41.

Mackenzie, F.T., Pigott, J.D., 1981. Tectonic controls of Phanerozoic sedimentary rock cycling Geologic Society of London Journal v. 138, p. 183-196, doi: 10.1144/gsjgs.138.2.0183.

Marín-Moreno, H., Minshull, T. A., Westbrook, G. K., Sinha, B., Sarkar, S., 2013. The response of methane hydrate beneath the seabed offshore Svalbard to ocean warming during the next three centuries. Geophys. Res. Lett. 40, 5159-5163 (2013).

Mau, S., Rehder, G., Arroyo, I.G., Gossler, J., Suess, E., 2007. Indications of a link between seismotectonics and $\mathrm{CH} 4$ release from seeps off Costa Rica. Geochem. Geophys. Geosyst. 8, 663 Q04003.

McKenzie, D., 1972. Active tectonics of the Mediterranean region. Geophys. J. R. Astron. Soc., 30, $109-185$.

Menot, G., Bard, E., 2010. Geochemical evidence for a large methane release during the last deglaciation from Marmara Sea sediments. Geochimica Et Cosmochimica Acta 74, $1537-1550$.

Mercier de Lépinay, B., Labeyrie, L., Çagatay, N., Beck, C., Schneider, J.-L., Cremer, M., Turon, J.-L., Londeix, L., Meyer, B., Gallet, Y., Pondard, N., MénotCombes, G., Hadjas, I., Cortijo, E., 2003. Interplay between recent sedimentation and active tectonics in Marmara Sea. AGU-EGS-EUG joint meeting, Nice.

Moore, J. C., Orange, D., Kulm, L. D., 1990. Interrelationship of fluid venting and structural evolution: Alvin observations from the frontal accretionary prism. J. Geophys. Res. 95, 8795-8808.

Morse, J.W., Wang, Q., Tsio, M.Y., 1997. Influences of temperature and Mg:Ca ratio on $\mathrm{CaCO}_{3}$ precipitates from seawater. Geology 25, 85-87. 
Naehr, T.H., Stakes, D.S., Moore, W.S., 2000. Mass wasting, ephemeral fluid fl ow, and barite deposition on the California continental margin: Geology 28, 315-318, doi: 10.1130/0091-7613(2000)282.0.CO;2.

Naehr, T.H., Eichhubl, P., Orphan, V.J., Hovland, M., Paull, C.K., Ussler Iii, W., Lorenson, T.D., Greene, H.G., 2007. Authigenic carbonate formation at hydrocarbon seeps in continental margin sediments: a comparative study. Deep Sea Res. Part II 54 (11-13), $1268-1291$.

Niemann, H., Duarte, J., Hensen, C., Omoregie, E., Magalhaes, V.H., Elvert, M., Pinheiro, L.M., Kopf, A., and Boetius, A., 2006. Microbial methane turnover at mud volcanoes of the Gulf of Cadiz. Geochim. Cosmochim. Acta 70, 5336-5355.

Obzhirov, A., Shakirov, R., Salyuk, A., Suess, E., Biebow, N., Salomatin, A., 2004. Relations between methane venting, geological structure and seismo-tectonics in the Okhotsk Sea. Geo-Marine Letters 24, 135-139.

Orphan, V.J., House, C.H., Hinrichs, K.-U., McKeegan, K.D., DeLong, E.F., 2001. Methaneconsuming archaea revealed by directly coupled isotopic and phylogenetic analysis. Science 293, 484-487.

Orphan, V.J., Ussler III, W., Naerh, T.H., House, C.H., Hinrichs, K.-U., Paull, C.K., 2004. Geological, geochemical and microbial heterogeneity of the seafloor around methane vents in the Eels River Basin, offshore California. Chem. Geol. 205, 265-289.

Öztürk, B., 2009. Investigations of the rose shrimp Parapenaeus longirostris (Lucas, 1846) in the Northern Marmara Sea. J. Black Sea/Mediterranean Environment 15, 123- 134.

Parsons, T., Toda, S., Stein, R. S., Barka, A., Dieterich, J. H., 2000. Heightenined odds of large earthquake near Istanbul: An interaction-based probability calculation, Science 288, 661-66.

Paull, C.K., Hecker, B., Commeau, R., Freeman-Lynde, R.P., Neumann, C., Corso, W.P., Golubic, S., Hook, J.E., Sikes, E., Curray, J., 1984. Biological communities at the Florida Escarpment resemble hydrothermal vent taxa. Science 226, 965-967.

Paull, C.K., Jull, A.J.T., Toolin, L.J., Linick, T., 1985. Stable isotope evidence for chemosynthesis in an abyssal seep community. Nature 317, 709-711.

Peckmann, J., Reimer, A., Luth, U., Luth, C., Hansen, B.T., Heinicke, C., Hoefs, J., Reitner, J., 2001. Methane-derived carbonates and authigenic pyrite from the northwestern Black Sea. Mar. Geol. 177, 129-150.

Peketi, A., Mazumdar, A., Joshi, R., Patil, D., Srinivas, P., Dayal, A., 2012. Tracing the paleo sulfate-methane transition zones and H2S seepage events in marine sediments: an application of C-S-Mo systematics. Geochem. Geophys. Geosyst. 13, Q10007. http://dx.doi.org/10.1029/2012GC004288.

Pierre, C., 2017. Origin of the authigenic gypsum and pyrite from active methane seeps of the southwest African Margin. Chemical Gology 449, 158 - 164.

Pierre, C., Blanc-Valleron, M.M., Demange, J., Boudouma, O., Foucher, J.P., Pape, T., Himmler, T., Fekete, N., Spiess, V., 2012. Authigenic carbonates from active methane seeps offshore southwest Africa. Geo-Marine Lett. 32, 501-554. doi:10.1007/s00367012-0295-x 
Quaiser, A., Zivanovic, Y., Moreira, D., López-Garcia, P., 2011. Comparative metagenomics of bathypelagic plankton and bottom sediment from the Sea of Marmara. ISME J. 5, 285-304.

Rank, D., Özsoy, E., Salihoglu, I., 1999. Oxygen-18, deuterium and tritium in the Black Sea and the Sea of Marmara. Journal of Environmental Radioactivity 43, 231-245.

Reagan, M. T., Moridis, G. J., Elliott, S. M. \& Maltrud, M. Contribution of oceanic gas hydrate dissociation to the formation of Arctic Ocean methane plumes. J. Geophys. Res. Oceans 116, C09014 (2011).

Reeburgh, W.S., 2007. Oceanic methane biogeochemistry. Chem. Rev. 107, 486-513. doi:10.1021/cr050362v

Reitner, J., Peckmann, J., Reimer, A., Schumann, G., Thiel, V., 2005. Methane-derived carbonate build-ups and associated microbial communities at cold seeps on the lower Crimean shelf (Black Sea). Facies 51, 71-84.

Ritt, B., Duperron, S., Lorion J., Lazar, C.S., Sarrazin, J., 2012. Integrative study of a new cold-seepmussel (Mollusca: Bivalvia) associated with chemosynthetic symbionts in the Marmara Sea. Deep-Sea Research I, 67, 121-132. http://dx.doi.org/10.1016/j.dsr.2012. 05.009 .

Ritt, B., Sarrazin, J., Caprais, J.-C., Noël, P., Gauthier, O., Pierre, C., Henry, P., Desbruyères, D., 2010. First insights into the structure and environmental setting of cold-seep communities in the Marmara Sea. Deep Sea Research Part I 57, 1120-1136.Ritt, B., Desbruyères, D., Caprais, J. C., Gauthier, O., Ruffine, L., Buscail, R., Olu-Le Roy, K., and Sarrazin, J., 2012. Seep communities from two mud volcanoes in the deep eastern Mediterranean Sea: faunal composition, spatial patterns and environmental control. Mar. Ecol.-Prog. Ser., 466, 93-119. Robinson, L.F., Belshaw, N.S., Henderson, G.M., 2004. $\mathrm{U}$ and Th concentrations and isotope ratios in modern carbonates and waters from the Bahamas. Geochim. Cosmochim. Acta 68, 1777-1789.

Ruffine, L., and Scientific team, 2014. Marsite Cruise Report, 1 - 13 November 2014. SixMonths Report, Vol. 2: Leg 2, 147 pages, Ifremer. http://dx.doi.org/10.17600/14000500.

Ruffine, L., Donval, J.P., Croguennec, C., Burnard, P., Lu, H., Germain, Y., Legoix, L., Bignon, L., Cagatay, M.N., Marty, B., Madre, D., Pitel-Roudaut, M., Henry, P., Géli, L., this issue (a). Multiple gas reservoirs are responsible for the gas emissions along the Marmara fault network. Deep-Sea Research Part II: Topical Studies in Oceanography.Ruffine L., Germain, Y., Polonia, A., De Prunele, A., Croguennec, C., Donval , J-P., Pitel-Roudaut, M., Ponzevera, E., Caprais , J-C., Brandily, C., Grall, C., Bollinger, C., Geli , L., and Gasperini, L., 2015. Pore water geochemistry at two seismogenic areas in the Sea of Marmara. Geochemistry Geophysics Geosystems, 16(7), 2038-2057.

Ruffine, L., Ondreasa, H., Blanc-Valleron, M-M., et al., this issue (b). Multidisciplinary investigation on cold seeps with vigorous gas emissions in the Sea of Marmara (MarsiteCruise): Strategy for site detection and sampling, scientific outcome and research roadmap. Deep-Sea Research Part II: Topical Studies in Oceanography.Şengör, A.M.C., Tüysüz, O., İmren, C., Sakınç, M., Eyidoğan, H., Görür, N., Rangin, C., 2005. the North Anatolian Fault: a New Look. Annual Review of Earth and Planetary Sciences 33(1), 37-112. doi:10.1146/annurev.earth.32.101802.120415. 
Şengör, A.M.C., Grall, C., İmren, C., Le Pichon, X., Görür, N., Henry, P., Karabulut, H., Siyako, M., 2014. The geometry of the North Anatolian transform fault in the Sea of Marmara and its temporal evolution: implications for the development of intracontinental transform faults. Canadian J. Earth Sci. 51(3), 222-242.

Taymaz, T., Jackson, J.A., McKenzie, D., 1991. Active tectonics of the North and Central Aegean Sea. Geophysical Journal International 106, 433-490.

Teichert1, B.M.A., Chevalier1, N. Gussone, N., Bayon, G., Ponzevera, E., Ruffine, L., Strauss, H., This issue. Sulfate-dependent anaerobic oxidation of methane at a highly dynamic bubbling site in the Eastern Sea of Marmara (Çinarcik Basin). Deep-Sea Research Part II: Topical Studies in Oceanography.Tolun, L., Çağatay, M.N., Carrigan, W.J., 2002. Organic geochemistry and origin of Late Glacial-Holocene sapropelic layers and associated sediments in Marmara Sea. Marine Geology, 190, 163-174.

Tryon, M.D., Henry, P., Çağatay, M.N., Zitter, T.A.C., Géli, M.L., Gasperini, L., Burnard, P., Bourlange, S., Grall, C., 2010. Pore fluid chemistry of the North Anatolian Fault Zone in the Sea of Marmara: a diversity of sources and processes. Geochemistry, Geophysics, Geosystems 11. doi:10.1029/2010GC003177.

Tryon, M. D., Henry, P., Hilton, D. R., 2012. Quantifying submarine fluid seep activity along the North Anatolian Fault Zone in the Sea of Marmara. Mar Geol. 315, 15-28.

Turgut, S., Türkarslan, M., Perinçek, D., 1991. Evolution of the Thrace sedimentary basin and its hydrocarbon prospectivity. In: A.M. Spencer (ed.), Generation, accumulation, and production of Europe's hydrocarbons. Special publication of the European Association of Petroleum Geoscientists No.1, pp. 415-437.

Tyler, P.A., German, C.R., Ramirez-Llodra, E., Van Dover, C.L., 2003. Understanding the biogeography of chemosynthetic ecosystems. Oceanol. Acta 25, 227-241.

Uçarkuş, G., Çakır, Z., Armijo, R., 2011. Western Termination of the Mw 7.4, 1999 İzmit Earthquake Rupture: Implications for the Expected Large Earthquake in the Sea of Marmara . Turkish Journal of Earth Sciences. 20, 379-394, doi:10.3906/yer-0911-72.

Valentine, D.L.,Reeburgh, W.S., 2000. New perspectives on anaerobic methane oxidation. Environmental Microbiology 2, 477-484.

Vidal, L., Menot, G., Joly, C., Bruneton, H., Rostek, F., Çağatay, M.N., Major, C., and Bard, E., 2010. Hydrology in the Sea of Marmara during the last 23 kyr: Implications for timing of Black Sea connections and sapropel deposition. Paleoceanography 25, PA1205, doi:10.1029/2009PA001735.

Zitter, T.A.C., Henry, M., Aloisi, G., Delaygue, G., Çağatay, M.N., Mercier de Lepinay, B., Al-Samir, M., Fornacciari, F., Tesmer, M., Pekdeğer, A., Wallmann, K., and Lericolais, G., 2008. Cold seeps along the main Marmara Fault in the Sea of Marmara (Turkey). Deep Sea Research Part I: Oceanographic Research Papers 55, 552-570.

Zitter, T.A.C., Grall, C., Henry, P., Özeren, M.S., Çağatay, M.N., Şengör, A.M.C., Gasperini, L., de Lépinay, B. M., Géli, L., 2012. Distribution, morphology and triggers of submarine mass wasting in the Sea of Marmara. Mar. Geol. 329-331, 58-74. 


\section{ACCEPTED MANUSCRIPT}

Fig. 1. (A) Morphotectonic map of Sea of Marmara (blue lines indicate faults after Uçarkuş et al., 2011: bathymetric data from Le Pichon et al., 2001). Detailed morphotectonic maps showing the location of authigenic carbonate samples (stars: this study; circless: Crémière et al., 2012): (B) western Sea of Marmara including the Tekirdağ and Westen High, (C) Central Basin, (D) Central High, (E) Çınacık Basin.

Fig. 2. Map of mud volcanoes on the central part of Western High, showing the sampling sites. For location see Fig. 1.

Fig. 3. Seafloor views of authigenic carbonates in southeastern Tekirdağ Basin. (A) A 7-cm thick carbonate crust (pavement) with deep water corals: site of sample DV04-CC04. (B) Carbonate crust near the chimney "Jack the Smoker" emitting brackish waters: site of sample DV04-CC01.

Fig. 4. Seafloor views authigenic carbonates in eastern Central Basin. (A) Carbonate pavement consisting of local discontinuous patches of carbonate crusts with a rough surface. Normal beige oxic sediments around the crusts contain 1-1.5 cm in diameter boring holes of pink shrimp, Parapenaeus longirostris (Lucas, 1846): site of 1661-R1. (B) Dark brown to black, flat, horizontally banded and fractured $3-\mathrm{cm}$ thick carbonate pavement at $-1143 \mathrm{~m}$ depth: site of sample 1661-R4. (C) A 2 m-high carbonate mound with its base fractured by faulting, -1141 m depth: 1661-R5. (D) A flat 0.6-0.8 cm thick carbonate pavement covered with $5 \mathrm{~mm}$ thick black reduced sediments and scarce dead bivalve shells, $-1140 \mathrm{~m}$ : site of sample 1661-R6. For locations of samples see Fig. 1C.

Fig. 5. Seafloor views authigenic carbonates in Çınarcık Basin. (A) A carbounate mound associated with black sulfidic patches, microbial mets and bivalves and corals: site of sample DV05-CC01. (B) A close of view of the same mound in (A) showing the deep water corals attached to the edge of the mound: site of sample DV05-Coral2. For locations of samples see Fig. 1E.

Fig. 6. Seafloor views of authigenic carbonates in Western High (A-E) and Central High (F). (A) Carbonate crust with black reduced sediments: site of sample DV02-CC02. (B) White barite precipitate with halos of black reduced sediments and bacterial mat; buff coloured sediments include borings of pink shrimp, Parapenaeus longirostris (Lucas, 1846) : near site of sample 1666-R1. (C) 6-7-cm thick mound like patches of carbonate crust with a rich bivalve population and surrounding patches of black reduced (sulphidic) sediments: site of sample DV02-CC03. For locations of samples on Western High see Fig. 1B. (D) Part of a 
ACCEPTED MANUSCRIPT

carbonate pavement covered by a few $\mathrm{cm}$ thick beige sediment. The surrounding sediments are predominantly beige with patches of black reduced sediments with rim of white microbial mat: site of sample 1664-R2. For locations of sample on Central High see Fig. 1B.

Fig. 7. Photographs of the authigenic carbonate crust samples (A) A $5 \mathrm{~cm}$-thick flat carbonate slab with tight cementation and white calcified tube worms, sample 1661-R3, eastern Central Basin. (B) A porous carbonate crust with sinter-like structure, sample 1661-R1, eastern Central Basin. (C) A carbonate crust sample with cemented mytilid bivalves (Idas modiolaeformis) in their living positions, 1664-R1, Central High. (D) Carbonate crust with botryoidal structure and Fe-oxide stained surface, sample DV04-CC01, SE Tekirdağ Basin. (E) Grey cavernous grey carbonate crust with bivalves, sample 1662-R1, Western High. (F) A $15 \mathrm{~cm}$-thick carbonate crust consisting of cemented rounded pebbles and shells, sample DV04-CC04, eastern Central Basin.

Fig. 8. Binocular microscope pictures of carbonate crusts with: (A) sugary texture, sample DV05-CC01, Çınarcık Basin, (B) and (C) serpulid tube worms on samples 1663-R3 (eastern Central Basin and DV04-CC04 (SE Tekirdağ Basin). (D) Red-brown Fe-oxyhydroxide filling worm tubes, sample 1662-R5 Western High.

Fig. 9. SEM microphotographs of authigenic carbonate crusts. (A) Differently oriented bundles of 100-200 $\mu \mathrm{m}$ long aragonite crystals. Sample contain honey-comb texture mineral (most likely authigenic smectite) with its surface covered by dark microbial organic matter. Sample 1664-1, Central High. (B) Cavity filling by aragonite of two different morphologies and stages, sample 1664-R1, Central High. (C) A laminated carbonate crust with a dark organic-rich smooth and a rough carbonate lamina. Sample DV04-CC-01, SE Tekirdağ Basin. (D) Fibrous, filamentous microbial organic matter covering walls of a solution cavity in sample DV04-CC-01, SE Tekirdağ Basin. (E) 3-5 $\mu \mathrm{m}$ long rice-like grains of high Mg-calcite in sample 1661-R3, eastern Central Basin. (F) A porous carbonate crust consisting mainly of a framework of calcified tube worms with some juvenile bivalves, echinoids, coccoliths and diatoms. Sample 1661-R1, eastern Central Basin.

Fig. 10. Histogram of absolute U-Th ages of carbonate crusts. The data are from this study and Crémière et al. (2013).

Fig. 11. Carbon and oxygen isotopic composition of seafloor authigenic carbonate crust samples from Sea of Marmara. 


\section{List of Tables}

Table 1. Geographic coordinates and water depths of authigenic carbonate crust, coral and barite samples.

\begin{tabular}{|c|c|c|c|c|c|}
\hline Sample & Latitude & Longitude & Location & Depth (m) & References \\
\hline 1647-R1 & 40.83405 & 27.503583 & W Tekirdağ Basin & 1056 & Cremiere et al. (2012) \\
\hline 1667-R1 & 40.803000 & 27.6296833 & SE Tekirdağ Basin & 1112 & Cremiere et al. (2012) \\
\hline 1667-R2 & 40.802983 & 27.629483 & SE Tekirdağ Basin & 1113 & Cremiere et al. (2012) \\
\hline $\begin{array}{l}\text { 1667-R3 } \\
\text { 1667-R3 }\end{array}$ & 40.801833 & 27.624333 & SE Tekirdağ Basin & 1118 & Cremiere et al. (2012) \\
\hline Chimney & 40.801833 & 27.624333 & SE Tekirdağ Basin & 1118 & Cremiere et al. (2012) \\
\hline DV04-CC01 & 40.803041 & 27.629529 & SE Tekirdağ Basin & 1107 & This study \\
\hline DV04-CC04 & 40.801790 & 27.623779 & SE Tekirdağ Basin & 1100 & This study \\
\hline 1649-R1 & 40.827033 & 27.9419 & W Central Basin & 1197 & Cremiere et al. (2012) \\
\hline 1661-R1 & 40.8583 & 28.1587667 & E Central Basin & 1156 & This study \\
\hline 1661-R2 & 40.8583 & 28.1587667 & E Central Basin & 1156 & This study \\
\hline 1661-R3 & 40.8580167 & 28.1591 & E Central Basin & 1159 & This study \\
\hline 1661-R4 & 40.8582 & 28.16175 & E Central Basin & 1143 & This study \\
\hline 1661-R5 & 40.8582167 & 28.161633 & E Central Basin & 1141 & This study \\
\hline 1661-R6 & 40.85705 & 28.167483 & E Central Basin & 1139 & This study \\
\hline 1661-R7 & 40.8570167 & 28.167483 & E Central Basin & 1139 & This study \\
\hline 1663-R1 & 40.85815 & 28.158217 & E Central Basin & 1155 & Cremiere et al. (2012) \\
\hline 1665-R1 & 40.854533 & 28.16975 & E Central Basin & 1111 & Cremiere et al. (2012) \\
\hline 1665-R2 & 40.854533 & 28.16975 & E Central Basin & 1111 & Cremiere et al. (2012) \\
\hline 1665-R3 & 40.854533 & 28.16975 & E Central Basin & 1111 & Cremiere et al. (2012) \\
\hline 1653-R3 & 40.705 & 29.156667 & Çınarcık Basin & 1212 & Cremiere et al. (2012) \\
\hline 1653-R5 & 40.70455 & 29.159067 & Çınarcık Basin & 1191 & Cremiere et al. (2012) \\
\hline 1658-R1 & 40.8138 & 29.0052 & Çınarcık Basin & 1176 & Cremiere et al. (2012) \\
\hline 1659-R1 & 40.716567 & 29.116267 & Çınarcık Basin & 1248 & Cremiere et al. (2012) \\
\hline DV05-CC01 & 40.71330 & 29.16925 & SE Çınarcık Basin & 1237 & This study \\
\hline 1662-R1 & 40.8176 & 27.779617 & Western High & 654 & This study \\
\hline 1662-R2 & 40.817833 & 27.780367 & Western High & 650 & Cremiere et al. (2012) \\
\hline 1662-R3 & 40.817667 & 27.780467 & Western High & 649 & Cremiere et al. (2012) \\
\hline 1662-R4 & 40.817683 & 27.78045 & Western High & 653 & This study \\
\hline 1662-R5 & 40.817683 & 27.78045 & Western High & 653 & This study \\
\hline DV02-CC03 & 40.814688 & 27.777024 & Western High & 646 & This study \\
\hline DV02-CC02 & 40.806382 & 27.73963 & Western High & 586 & This study \\
\hline 1664-R1 & 40.86175 & 28.583533 & E Central High & 323 & This study \\
\hline 1664-R2 & 40.86185 & 28.583433 & E Central High & 326 & This study \\
\hline
\end{tabular}




\section{ACCEPTED MANUSCRIPT}

\begin{tabular}{llllll} 
1666-R1 (Barite) & 40.815 & 27.777 & Western High & 656 & This study \\
DV05-CORAL2 & 40.71126 & 29.16656 & SE Çınarcık Basin & 1240 & This study \\
1661-R3-CORAL & 40.8580167 & 28.1591 & E Central Basin & 1159 & This study \\
\hline
\end{tabular}

Table 2. Mineralogical, stable isotope compositions and U-Th ages of authigenic carbonate cement, coral and barite samples from the Sea of Marmara.

\begin{tabular}{|c|c|c|c|c|c|c|c|}
\hline \multirow[b]{2}{*}{ Sample } & \multirow[b]{2}{*}{$\delta^{13} \mathrm{C} \%$} & \multirow[b]{2}{*}{$\delta^{18} \mathrm{O} \%$} & \multicolumn{4}{|c|}{ Carbonate minerals (relative $\%$ ) } & \multirow{2}{*}{$\begin{array}{l}\mathrm{U} / \mathrm{Th} \\
\text { isochron age } \\
\text { (ka) }\end{array}$} \\
\hline & & & Aragonite & Calcite & $\begin{array}{l}\mathrm{Mg}- \\
\text { Calcite }\end{array}$ & Dolomite & \\
\hline 1647-R1* & -27.9 & 2.6 & 100 & - & - & - & $1.01 \pm 0.30^{*}$ \\
\hline 1667-R1* & -37.3 & 1.3 & 91 & 9 & - & - & $0.59 \pm 0.03 *$ \\
\hline 1667-R2* & -40.4 & 1.9 & 38 & 5 & 57 & - & \\
\hline 1667-R3* & -34.7 & 2.0 & 61 & 6 & 33 & - & \\
\hline 1667-R3 & & & & & & & \\
\hline Chimney* & -29.1 & 1.3 & 54 & 9 & 37 & - & \\
\hline DV04-CC01 & -42.1 & 1.3 & 85 & - & 15 & - & $0.58 \pm 0.14$ \\
\hline DV04-CC04 & -36.3 & 1.6 & 63 & 26 & 7 & 4 & \\
\hline 1649-R1* & -39.9 & 0.5 & 16 & 23 & 61 & - & \\
\hline 1661-R1 & -47.6 & 3.1 & 93 & 5 & - & 2 & \\
\hline 1661-R2 & -44.4 & 3.0 & 100 & - & - & - & $3.92 \pm 0.87 *$ \\
\hline 1661-R3 & -29.8 & 1.8 & - & - & 100 & - & \\
\hline 1661-R4 & -42.4 & 2.0 & 50 & 50 & - & - & $9.61 \pm 2.40$ \\
\hline 1661-R5 & -37.5 & 2.2 & 95 & 5 & 2 & - & $9.14 \pm 2.29$ \\
\hline 1661-R6 & -43.9 & 3.8 & 5 & - & 95 & - & \\
\hline 1661-R7 & -36.6 & 2.0 & 23 & 33 & 37 & 7 & \\
\hline 1663-R1* & -41.0 & 2.5 & 40 & 15 & 23 & 22 & \\
\hline 1665-R1* & -45.6 & 2.9 & 89 & 3 & 8 & - & \\
\hline $1665-\mathrm{R} 2 *$ & -47.2 & 2.5 & 43 & 6 & 46 & 5 & \\
\hline 1665-R3* & -40.1 & 2.9 & 18 & - & 67 & 15 & \\
\hline 1653-R3* & -41.8 & 2.1 & 87 & 8 & 5 & - & $6.63 \pm 0.52^{*}$ \\
\hline 1653-R5* & -36.5 & 2.5 & 100 & - & - & - & $0.43 \pm 0.06^{*}$ \\
\hline 1658-R1* & -46.4 & 2.3 & 93 & 5 & 2 & - & \\
\hline 1659-R1* & -29.6 & 2.3 & 77 & 7 & 16 & - & \\
\hline DV05-CC01 & -43.8 & 3.1 & 54 & 44 & 2 & - & $0.11 \pm 0.03$ \\
\hline 1662-R1 & -13.6 & 3.3 & 95 & 5 & - & - & $6.50 \pm 0.87 *$ \\
\hline 1662-R2* & -22.6 & 2.7 & 94 & 5 & 1 & - & \\
\hline 1662-R3* & -36.6 & 2.6 & 69 & 6 & 22 & 3 & \\
\hline 1662-R4 & -23.2 & 3.4 & 67 & 5 & 28 & - & $1.30 \pm 0.31^{*}$ \\
\hline 1662-R5 & -24.9 & 3.1 & 97 & 3 & - & - & $2.19 \pm 0.09^{*}$ \\
\hline DV02-CC03 & -14.8 & 3.2 & 97 & 3 & - & - & \\
\hline DV02-CC02 & -35.4 & 3.2 & 96 & 4 & - & - & \\
\hline 1664-R1 & -18.1 & 2.8 & 85 & 10 & 5 & - & $3.28 \pm 0.19^{*}$ \\
\hline 1664-R2 & -20.2 & 2.9 & 99 & 1 & - & - & $0.53 \pm 0.13$ \\
\hline 1666-R1 (Barite) & -0.6 & 3.2 & 100 & - & - & - & \\
\hline DV05-CORAL2 & -4.6 & 1.2 & 99 & 1 & - & - & $0.63 \pm 0.16$ \\
\hline
\end{tabular}


*Data from Crémière et al $(2012,2013)$

Table 3. ICP-MS/ES elemental composition of authigenic carbonates analysed in this study.

\begin{tabular}{lllllllllllll}
\hline Sample & $\mathrm{Ca}$ & $\mathrm{Mg}$ & $\mathrm{Al}$ & $\mathrm{Fe}$ & $\mathrm{K}$ & $\mathrm{S}$ & $\mathrm{Mn}$ & $\mathrm{Mo}$ & $\mathrm{Sr}$ & $\mathrm{Ba}$ & $\mathrm{Rb}$ & $\mathrm{Li}$ \\
Number & $\mathrm{wt} \%$ & $\mathrm{wt} \%$ & $\mathrm{wt} \%$ & $\mathrm{wt} \%$ & $\mathrm{wt} \%$ & $\mathrm{wt} \%$ & $\mu \mathrm{g} / \mathrm{g}$ & $\mu \mathrm{g} / \mathrm{g}$ & $\mu \mathrm{g} / \mathrm{g}$ & $\mu \mathrm{g} / \mathrm{g}$ & $\mu \mathrm{g} / \mathrm{g}$ & $\mu \mathrm{g} / \mathrm{g}$ \\
\hline DV02 CC03 & 33.33 & 0.27 & 1.11 & 0.53 & 0.29 & $<0.1$ & 135 & 1.4 & 7297 & 59 & 18.5 & 9.0 \\
DV02 CC02 & 31.73 & 0.47 & 1.38 & 0.69 & 0.38 & 0.1 & 153 & 1.1 & 6730 & 149 & 21.8 & 9.7 \\
DV04 CC01 & 32.17 & 0.30 & 0.16 & 3.51 & 0.06 & 3.8 & 295 & 55.2 & 6267 & 280 & 2.8 & 2.2 \\
DV04 CC04 & 14.38 & 1.10 & 3.63 & 1.55 & 1.44 & 0.6 & 609 & 9.3 & 2606 & 459 & 61.3 & 18.9 \\
DV05 CC01 & 12.99 & 0.27 & 0.09 & 0.05 & 0.17 & 0.4 & 23 & 14.3 & 6072 & 221 & 1.3 & 1.4 \\
1661 R1 & 32.24 & 0.81 & 1.41 & 0.82 & 0.39 & 0.1 & 469 & 3.0 & 7694 & 154 & 22.9 & 10.6 \\
1661 R2 & 35.01 & 0.50 & 1.16 & 0.60 & 0.32 & $<0.1$ & 851 & 3.1 & 7203 & 413 & 18.5 & 9.0 \\
1661 R3 & 28.86 & 2.22 & 2.15 & 0.95 & 0.68 & 0.1 & 396 & 1.5 & 482 & 262 & 37.3 & 17.1 \\
1661 R4 & 36.32 & 0.83 & 0.27 & 0.25 & 0.08 & $<0.1$ & 1007 & 3.6 & 5622 & 601 & 4.5 & 2.8 \\
1661 R5 & 38.68 & 0.55 & 0.10 & 0.10 & 0.03 & $<0.1$ & 939 & 2.4 & 7485 & 744 & 1.5 & 1.8 \\
1661 R6 & 30.30 & 3.06 & 1.07 & 0.54 & 0.31 & 0.1 & 1868 & 2.2 & 2032 & 348 & 17.3 & 8.9 \\
1661 R7 & 26.58 & 2.82 & 1.84 & 1.26 & 0.55 & 0.5 & 1464 & 14.9 & 2641 & 470 & 29.5 & 15.3 \\
1662 R1 & 30.18 & 0.51 & 2.06 & 1.05 & 0.58 & 0.1 & 208 & 4.2 & 6801 & 184 & 33.1 & 16.9 \\
1662 R4 & 29.75 & 1.35 & 1.95 & 0.99 & 0.52 & 0.3 & 221 & 20.2 & 5737 & 89 & 31.0 & 15.9 \\
1662 R5 & 32.57 & 0.57 & 1.51 & 0.85 & 0.40 & 0.2 & 326 & 11.0 & 7390 & 70 & 24.7 & 11.9 \\
1664 R1 & 22.73 & 0.97 & 3.57 & 1.85 & 0.94 & 0.6 & 249 & 41.9 & 4534 & 177 & 54.9 & 27.7 \\
1664 R2 & 37.17 & 0.12 & 0.24 & 0.12 & 0.07 & 0.2 & 19 & 23.6 & 8348 & 37 & 3.9 & 2.5 \\
\hline
\end{tabular}

Table 4. Measured U-Th data $( \pm 2 \sigma)$ for Marmara authigenic carbonate crusts and activity ratios used for isochron age calculation

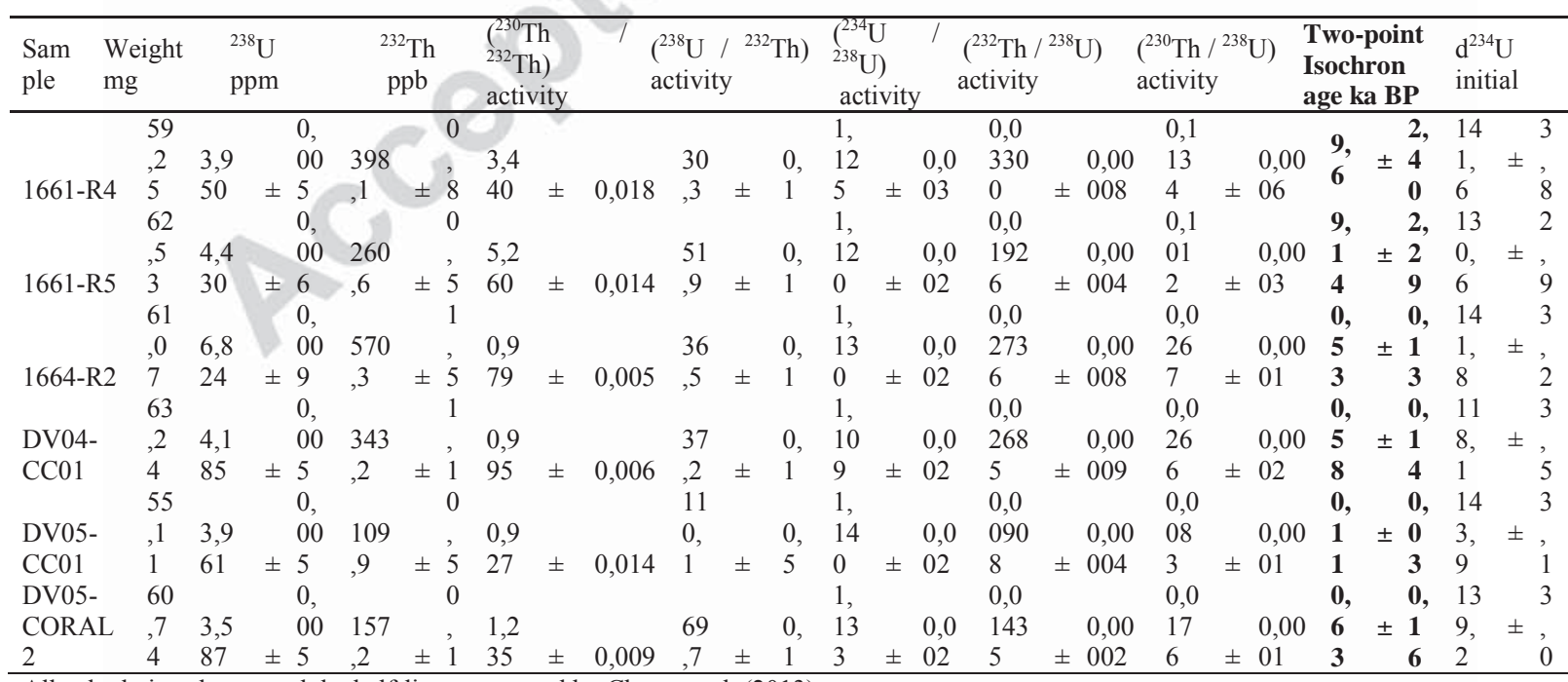

All calculations have used the half-lives measured by Cheng et al. (2013).

Two-point isochron ages were calculated using an experimental end-member determined from sediment analyses (see values in Crémière et al., 2013; samples 1-6) 


\section{ACCEPTED MANUSCRIPT}

or a sediment end-member at secular equilibrium (i.e. activity ratio $=1 \pm 0.5$; samples 7-12).

All isochron ages were given an arbitrary 25\% error based on previous estimates (Bayon et al., 2013).

Initial $\mathrm{d}^{234} \mathrm{U}=\left(\left[{ }^{234} \mathrm{U} /{ }^{238} \mathrm{U}\right]\right.$ activity -1$) \times 1000$, based on isochron ${ }^{230} \mathrm{Th}$ age and corrected from detrital contamination.

B.P. stands for "Before Present" where the "Present" is defined as the year 1950 A.D.
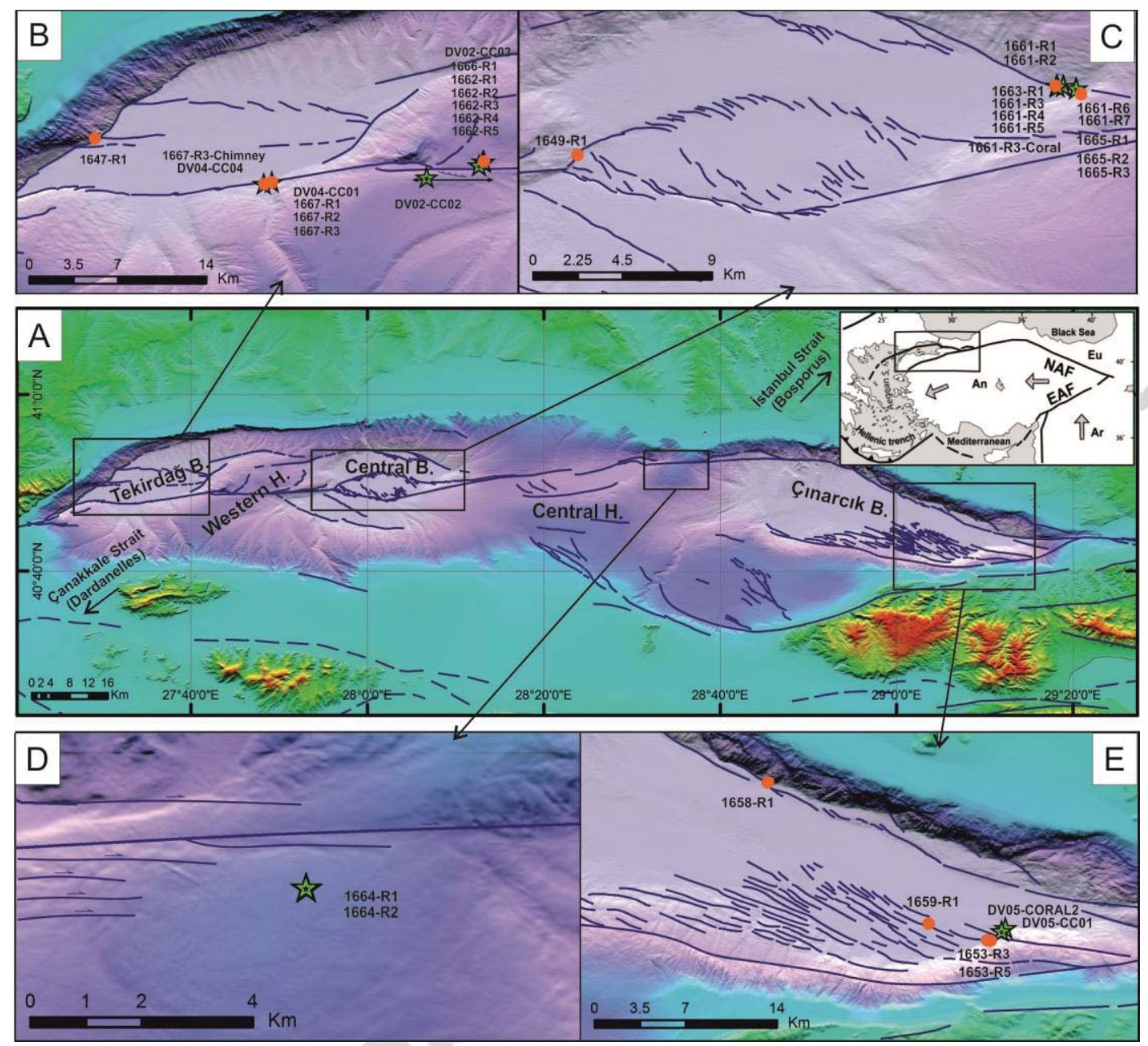

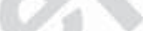

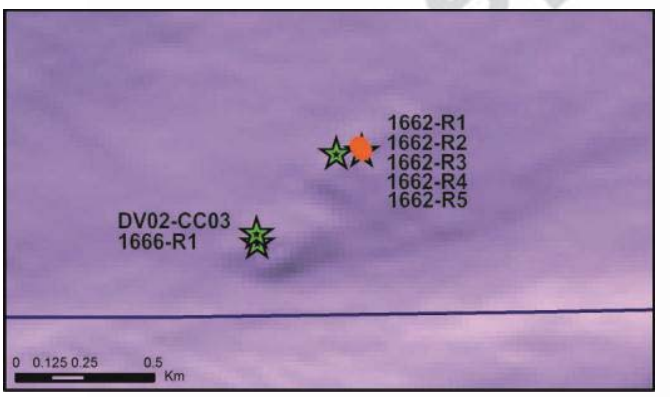



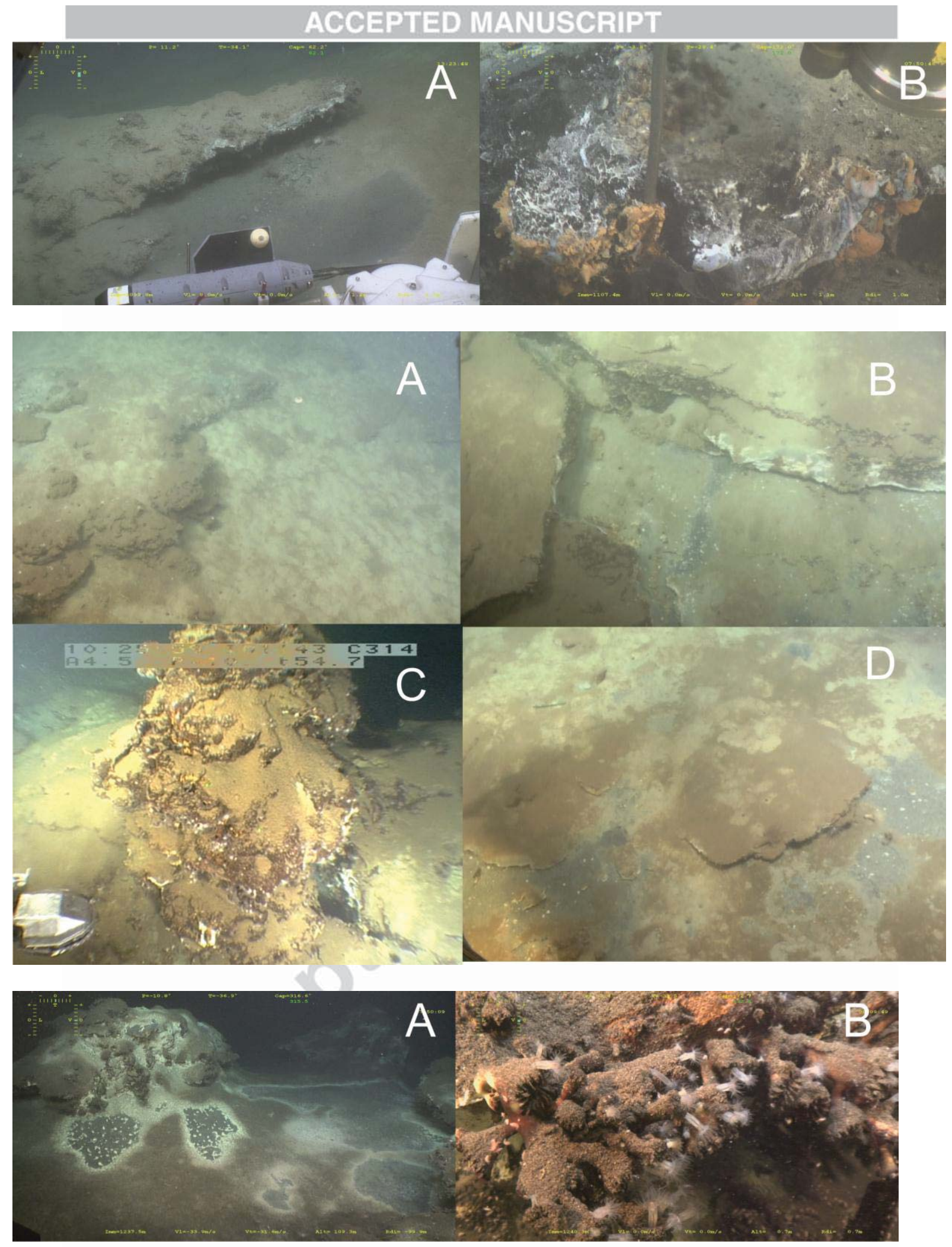


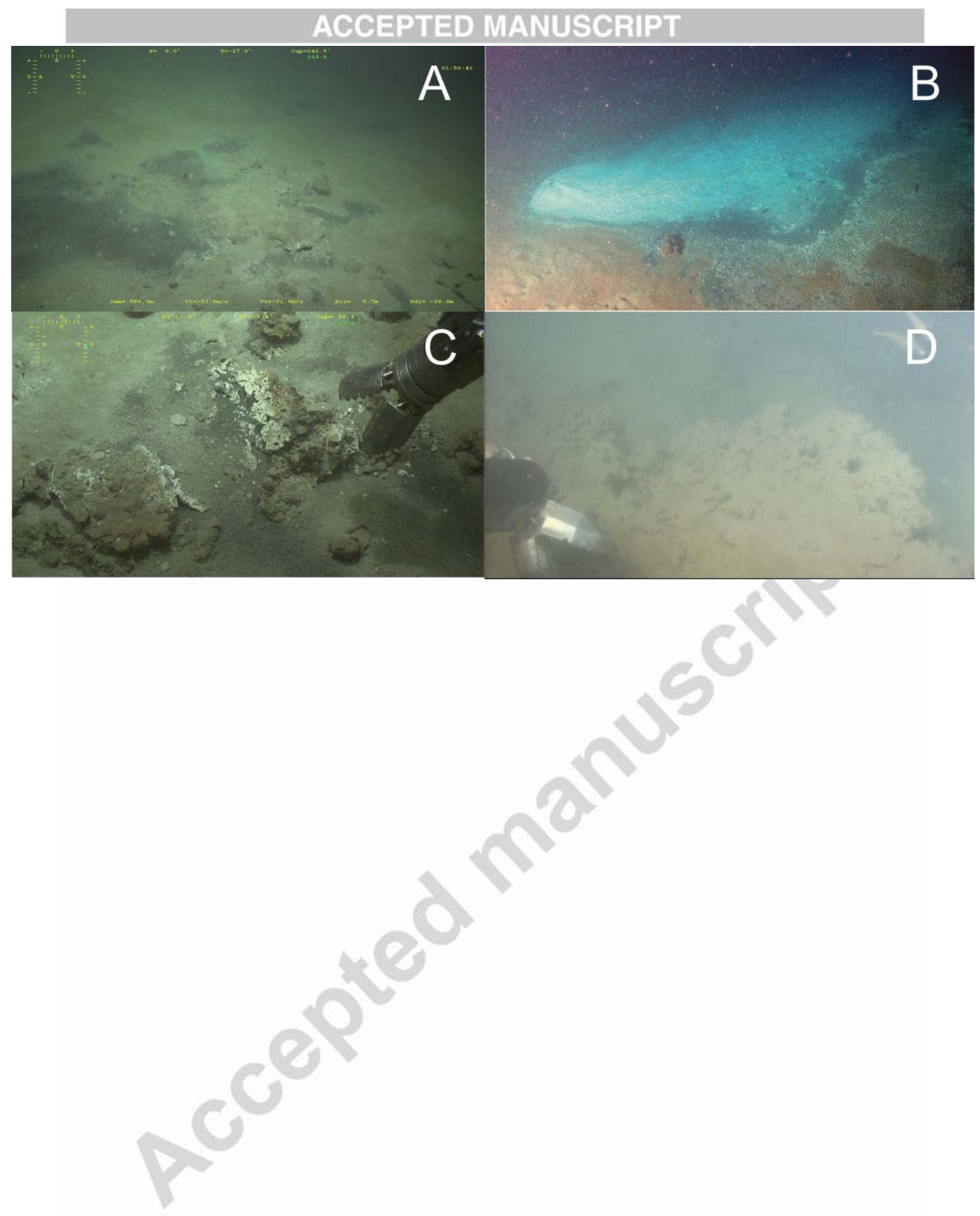




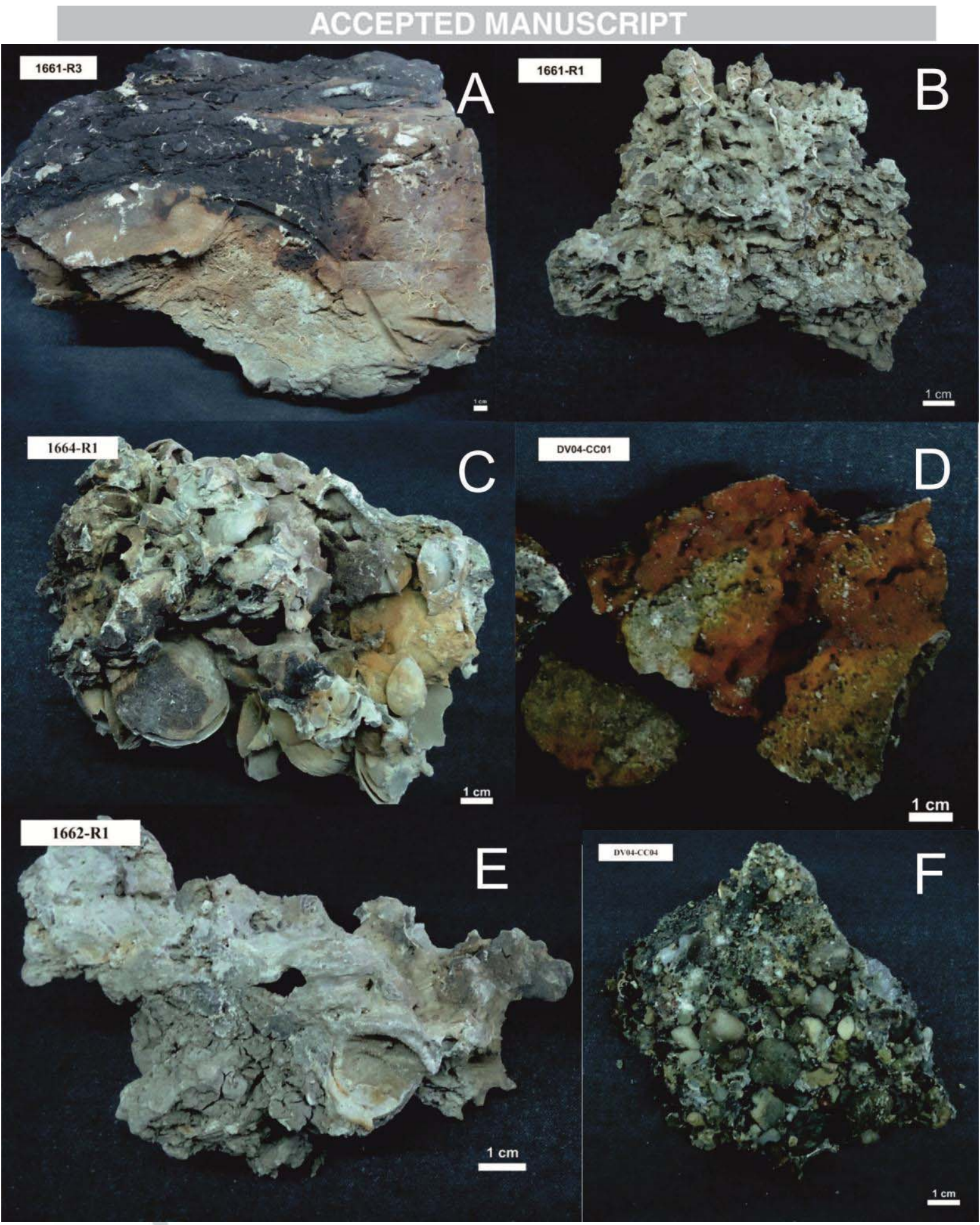




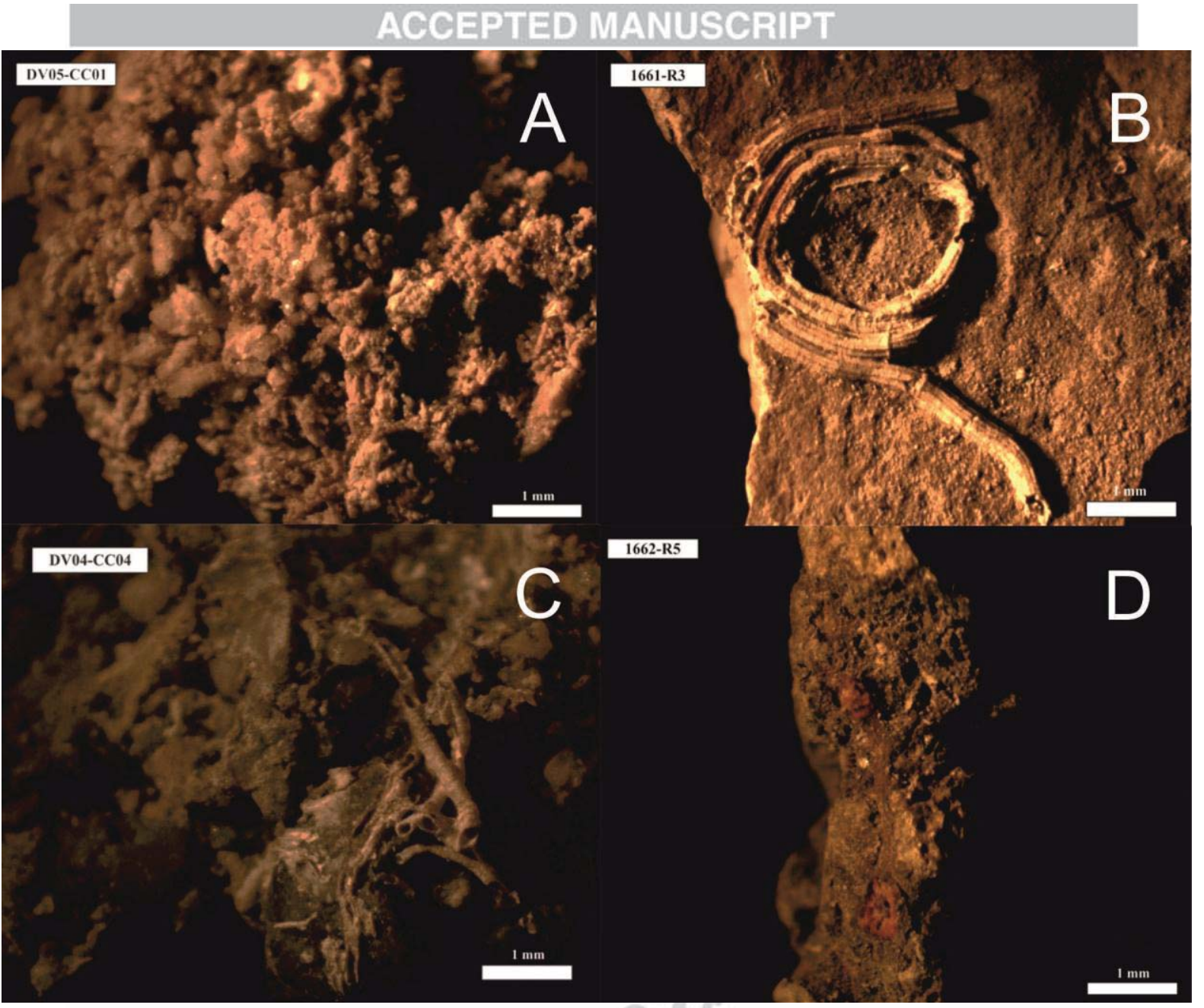




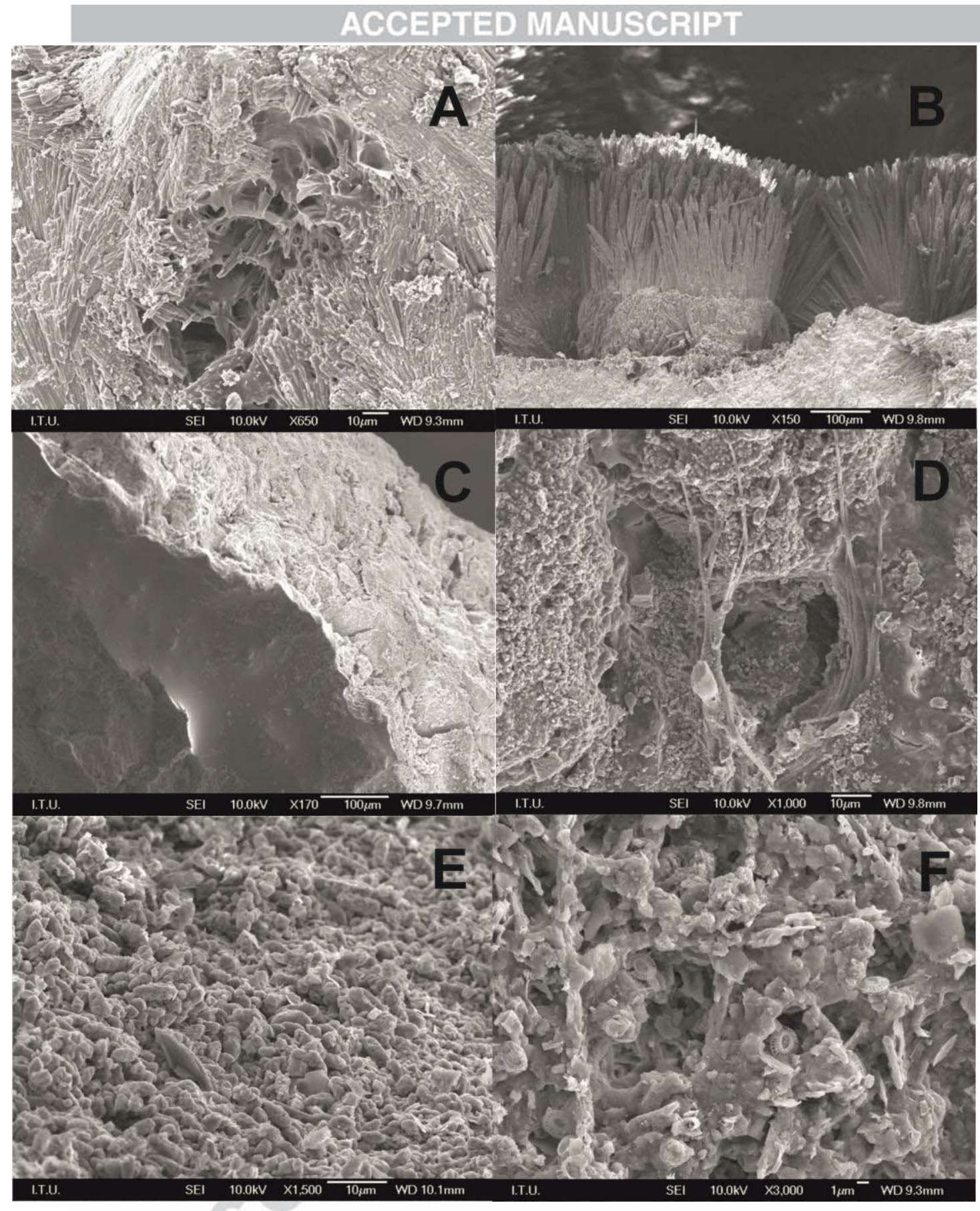




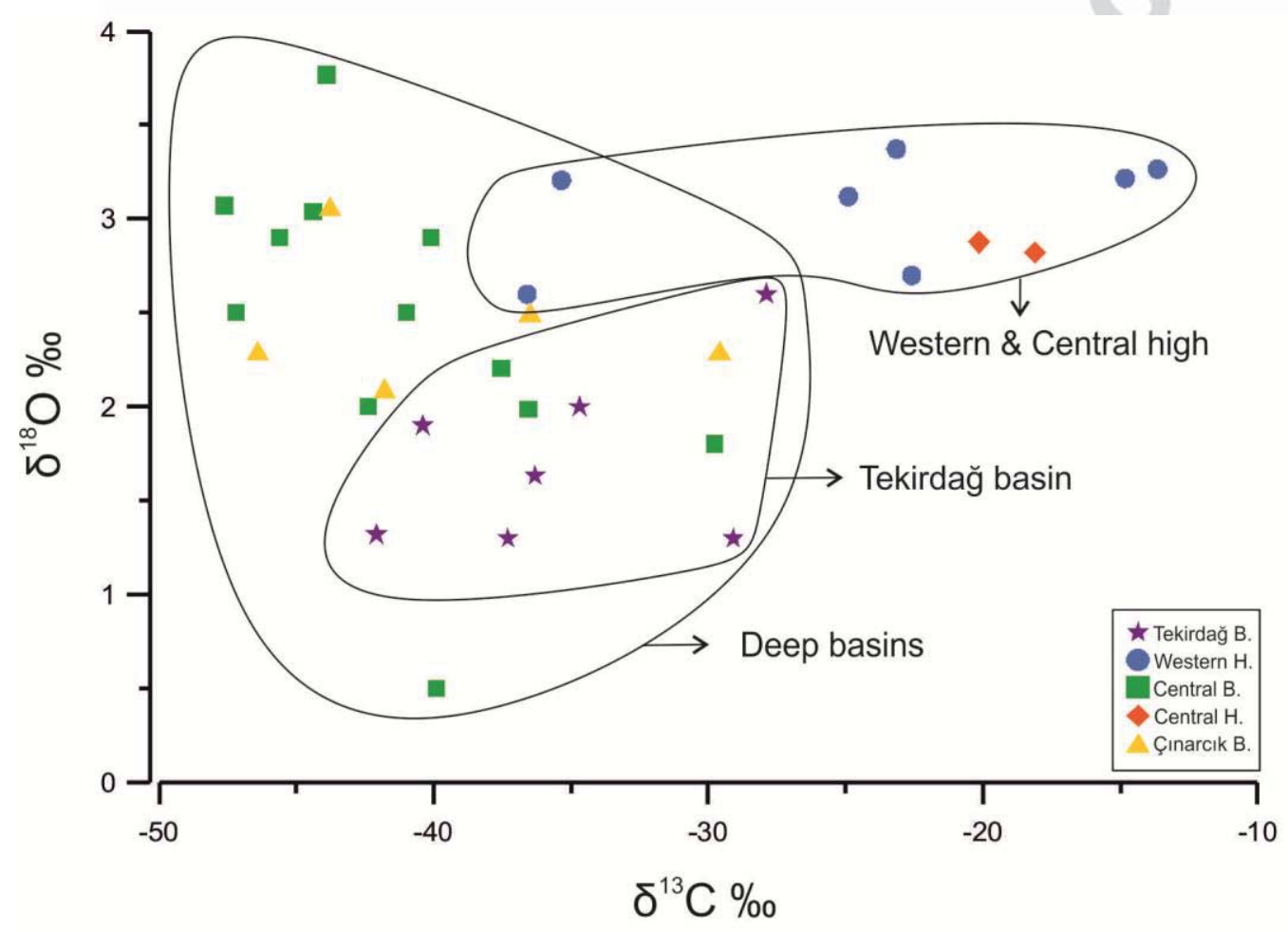

